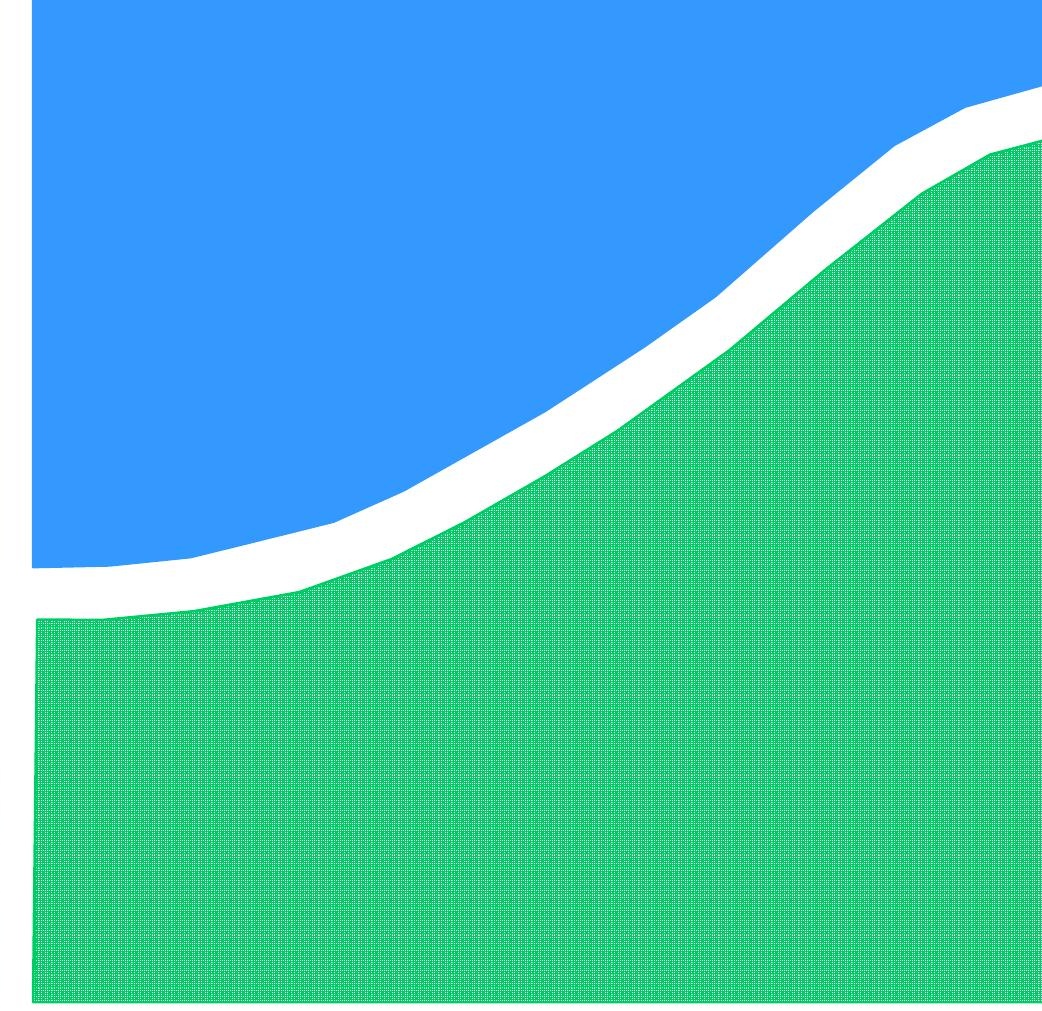

PROJETO DE GRADUAÇÃO

\title{
PROJETO DE MÁQUINA DE APLICAÇÃO DE CARGA PARA ENSAIO EM MESAS
}

\author{
Por, \\ Tarcisio Bruno Ribeiro
}

Brasília, Julho de 2009

\section{UNIVERSIDADE DE BRASÍLIA}

FACULDADE DE TECNOLOGIA

DEPARTAMENTO DE ENGENHARIA MECÂNICA 


\title{
PROJETO DE GRADUAÇÃO
}

\section{PROJETO DE MÁQUINA DE APLICAÇÃO DE CARGA PARA ENSAIO EM MESAS}

\author{
POR, \\ Tarcisio Bruno Ribeiro
}

Relatório submetido como requisito parcial para obtenção

do grau de Engenheiro Mecânico.

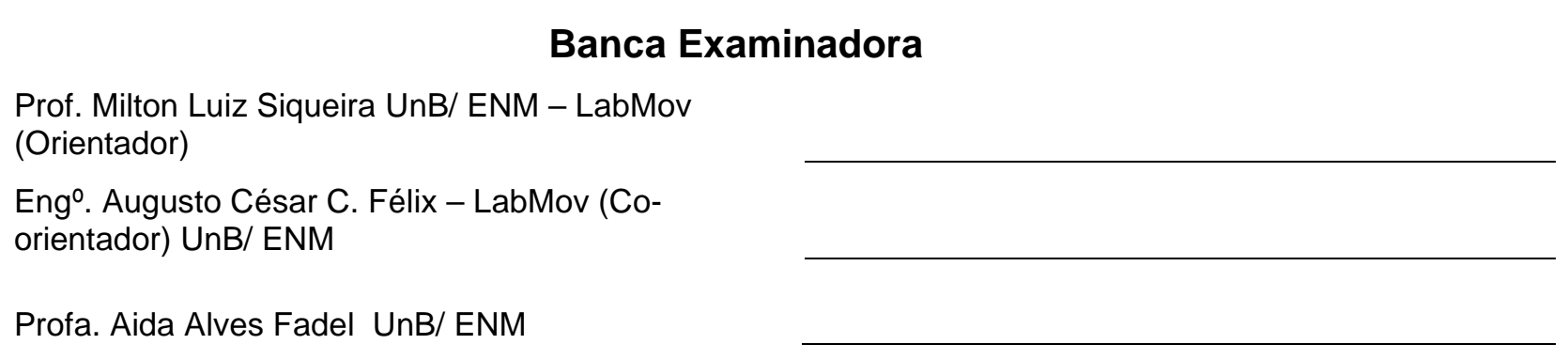

Brasília, Julho de 2009 


\section{Agradecimentos}

Agradeço à minha família pelo apoio incondicional e pela compreensão, além do compreensível, do meu processo.

Agradeço ainda aos membros do LabMov, em especial ao meu orientador Milton Luiz. Siqueira e a meu co-orientador Augusto Félix pelos conhecimentos a mim transmitidos.

Tarcisio Bruno Ribeiro 
A indústria de móveis vem aumentando significativamente sua linha de produção e tem procurado certificar seus móveis, em conformidade com o INMETRO e às normas ABNT, para que possam participar de licitações públicas. São poucos os laboratórios de ensaio em móveis acreditados pelo INMETRO no Brasil e o LabMov da Universidade de Brasília é um deles, além de ser o único laboratório da região centro oeste, norte e nordeste com tal acreditação. Um dos escopos do LabMov é o ensaio de mesas e para tanto, tem desenvolvido e construído uma máquina de ensaio de mesa de até $6 \mathrm{~m}$ de comprimento. Portanto, foram projetados e simulados os vários elementos da máquina existente para ensaio em mesas, que foi construída no Laboratório de Ensaio em Móveis da Universidade de Brasília. O projeto resultou da necessidade de otimização dos ensaios em mesas do LabMov, sendo fundamentado sob a Norma ABNT NBR 13966:2008. Tratou basicamente do dimensionamento e seleção de componentes substitutos para a máquina de ensaios horizontais existente. Verificou-se que alguns componentes não estavam com a rigidez adequada para o ensaio, foi necessário estabelecer aumento da rigidez modificando a geometria e espessura dos elementos de máquina e foi necessário, também, projetar um novo dispositivo para ensaios de cargas estáticas e dinâmicas verticais que deve funcionar como complemento para atender as exigências da referida norma.

ABSTRACT

The furniture industry has increased significantly its production line and has sought to make their furniture in accordance with INMETRO and ABNT, so they can participate in public tenders. Few laboratories test mobile accredited by INMETRO LabMov in Brazil and the University of Brasília is one of them, besides being the only laboratory in the central west, north and northeast regions with such accreditation. One of the goals of LabMov is the test for both tables and has developed and built a testing machine table up to $6 \mathrm{~m}$ in length. So, were designed and simulated the various elements of the machine to test tables, which was built in the Laboratory Test in Mobile at the University of Brasilia. The project resulted from the need to optimize the testing of LabMov tables, being based in the ABNT NBR 13966:2008. One of the goals of LabMov is the test for both tables and has developed and built a testing machine table up to $6 \mathrm{~m}$ in length. So, were designed and simulated the various elements of the machine to test tables, which was built in the Laboratory Test in Mobile at the University of Brasilia. The project resulted from the need to optimize the testing of LabMov tables, being based on the ABNT NBR 13966:2008. This was basically the sizing and selection of replacement components for machine testing existing horizontal. It was found that some components did not have the necessary rigidity to the test, it was necessary to increase the stiffness by changing the geometry and thickness of the elements of machine and it was also necessary to design a new device for testing the static and dynamic vertical should serve as a complement to meet the requirements of this standard. 


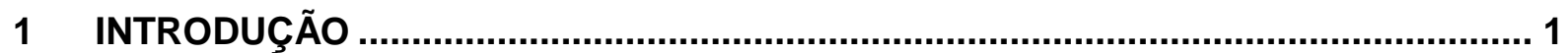

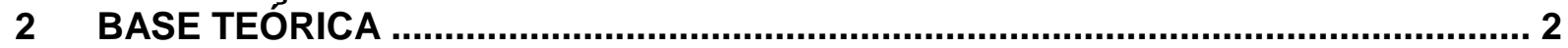

$2.1 \quad$ NORMA REGULAMENTADORA

2.1.1 Requisitos Dimensionais Para Mesas de Trabalho ………...................................................... 2

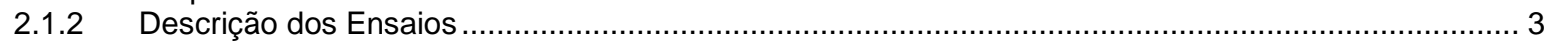

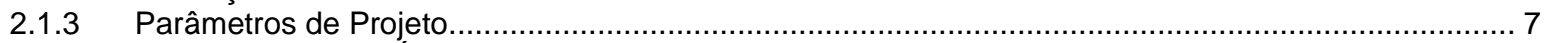

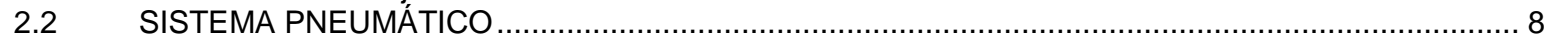

2.2.1 Características dos Sistemas Pneumáticos ............................................................................ 10

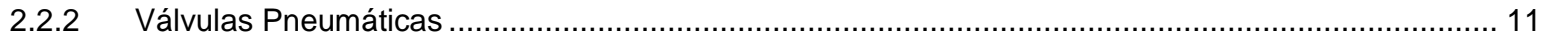

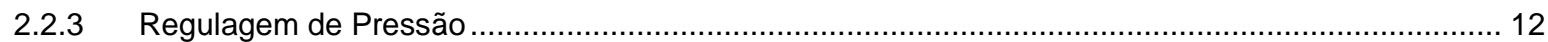

2.2.4 Atuadores Pneumáticos …………………........................................................................ 13

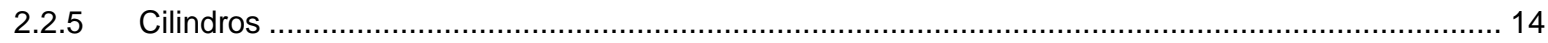

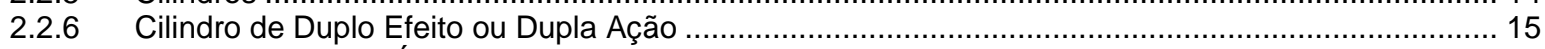

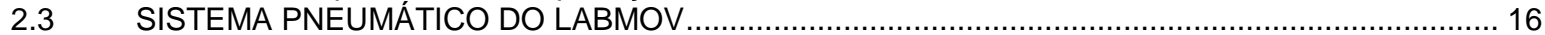

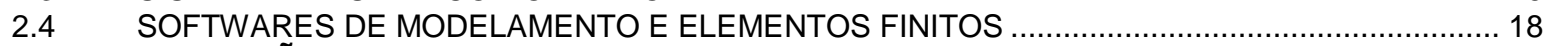

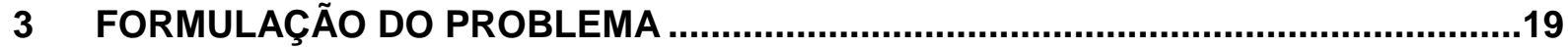

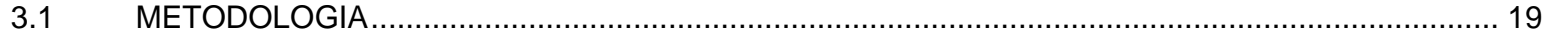

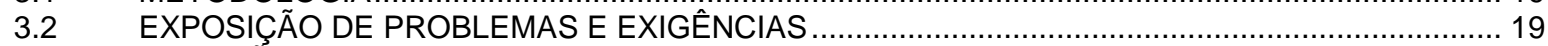

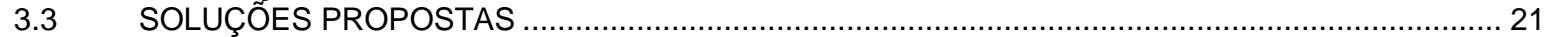

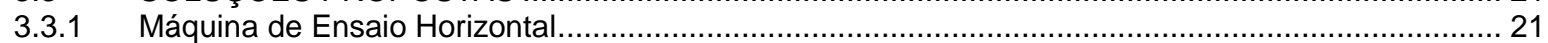

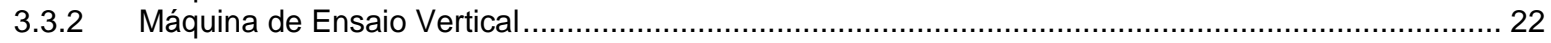

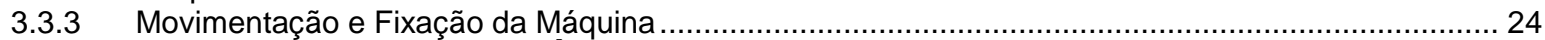

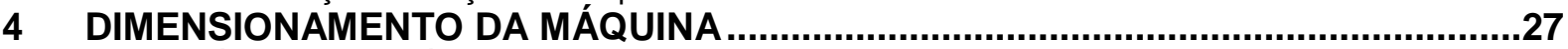

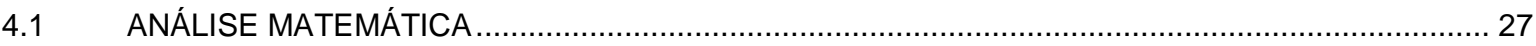

4.1.1 Cálculo dos Esforços nos Carregamentos de Ensaios Horizontais ............................................... 27

4.1.2 Cálculo dos Esforços nos Carregamentos de Ensaios Verticais ...................................................... 28

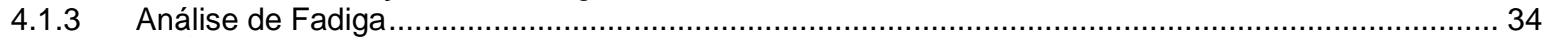

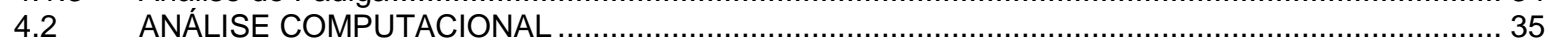

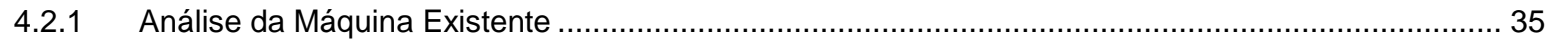

4.2.2 Análise da Proposta para a Parte de Ensaio Horizontal ................................................................... 37

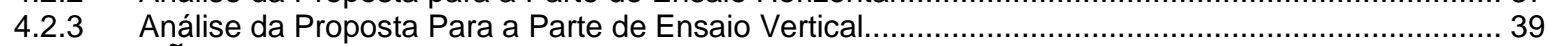

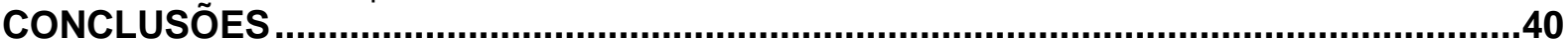

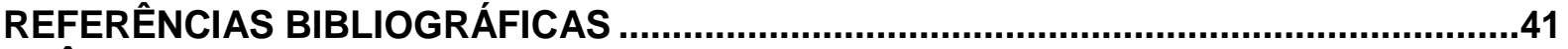

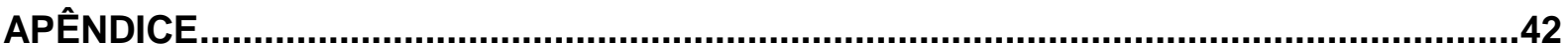


2.1 Ensaio de estabilidade sob aplicação de carga vertical (LabMov) ...................... 4

2.2 Posição de aplicação de cargas para ensaio de resistência (LabMov) ) .................. 4

2.3 Mesa preparada para ensaios horizontais (LabMov) ................................... 5

2.4 Pontos de aplicação de carga para ensaio de resistência vertical (LabMov) ..............6

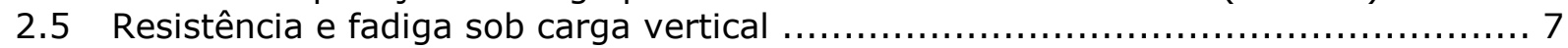

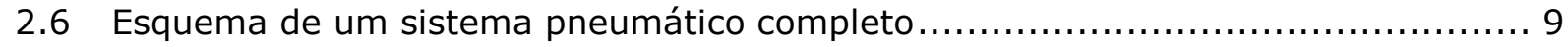

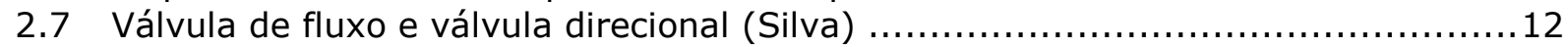

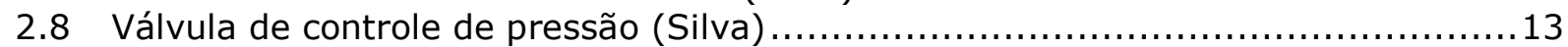

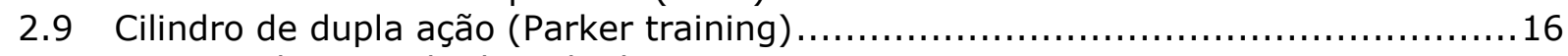

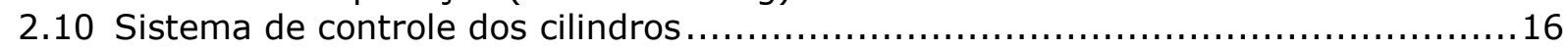

3.1 Detalhe da pinça de fixação da barra................................................. 20

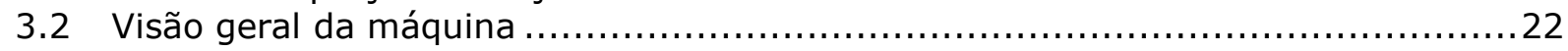

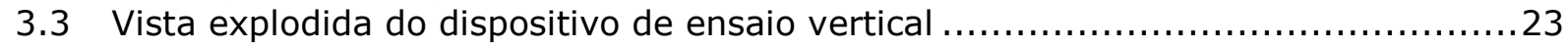

3.4 Detalhe da imobilização da barra do carro horizontal ................................24

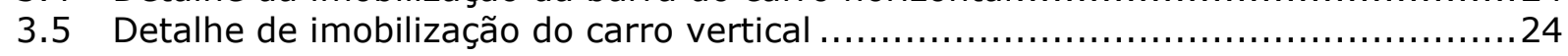

4.1 Diagrama de corpo livre do carro................................................. 17

4.2 Barra de apoio do carro. A escala cromática à direita indica a deformação ...........19

4.3 Barra de apoio do carro. A escala cromática à direita indica as tensões ..............19

4.4 Perfil em U da barra de apoio. Simulação realizada no pacote COSMOSXpress ${ }^{\circledR} \ldots .20$

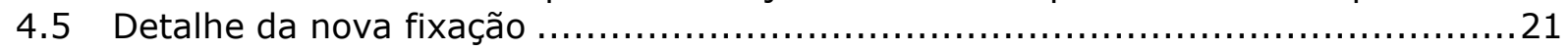

4.6 Carro de ensaio vertical. Esquema da estrutura treliçada ............................22

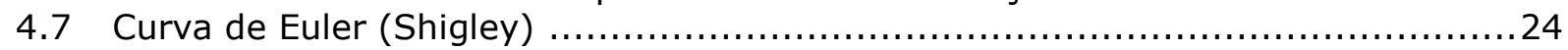




\section{LISTA DE TABELAS}

Tabela 1 Dimensões determinantes (ABNT NBR 13966:2008) $\ldots \ldots \ldots \ldots \ldots \ldots \ldots \ldots \ldots$

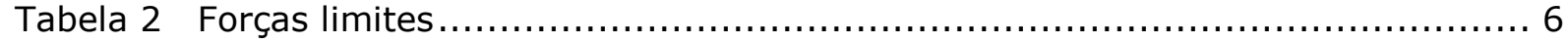

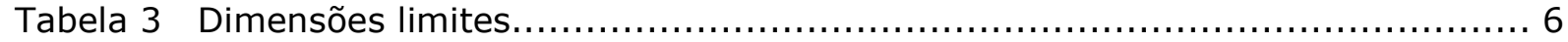

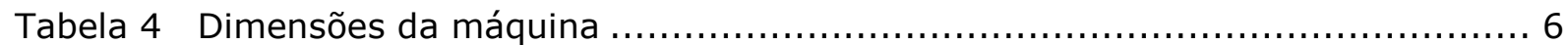

Tabela 5 Detalhamento dos equipamentos pneumáticos usados no LabMov ...............16

Tabela 6 Comparativo entre as peças ..................................................... 33

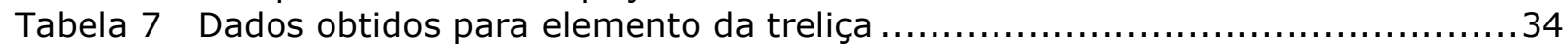




\section{Símbolos Latinos}

A Área

I Momento de inércia

$\left[\mathrm{m}^{2}\right]$

$k \quad$ Raio de giração

$S_{Y} \quad$ Tensão de escoamento

$E \quad$ Módulo de elasticidade

[MPa]

$\varepsilon \quad$ Deformação

$F \quad$ Força

[GPA]

M Momento

\section{Subscritos}

cr Crítico

\section{Siglas}

$\begin{array}{ll}\text { ABNT } & \text { Associação Brasileira de Normas Técnicas } \\ \text { LabMov } & \text { Laboratório de Ensaio em Móveis } \\ \text { Inmetro } & \text { Instituto Nacional de Metrologia, Normalização e Qualidade Industrial } \\ \text { MEF } & \text { Método dos Elementos Finitos } \\ \text { MLP } & \text { Módulo Lógico Programável }\end{array}$




\section{INTRODUÇÃO}

O Laboratório de Ensaio em Moveis (LabMov) da Universidade de Brasília, é o único laboratório da região com capacidade para realizar ensaio em móveis. Em consequiência disso, o LabMov tem sido muito procurado pela indústria de móveis de todo o pais para certificarem seus móveis, principalmente aquelas indústrias que participam ou pretendem participar de licitações e que precisam ter obrigatoriamente seus móveis acreditados às exigências de conformidade do INMETRO e da ABNT.

O LabMov tem sido constantemente auditado pelo INMETRO, junto ao qual possui acreditação em ensaios de móveis de escritório. Todas as máquinas e dispositivos de carga são desenvolvidos pelo próprio LabMov, portanto o desenvolvimento de máquinas, otimização, inovação e a automação são assuntos correntes no cotidiano do laboratório. A crescente demanda incorre em uma constante necessidade de aprimoramento, otimização e desenvolvimento dos dispositivos envolvidos nos ensaios, de forma que a qualidade e a precisão destes estão diretamente relacionadas com a qualidade dos projetos e da construção das máquinas e dispositivos para ensaio. Obtêm-se, como conseqüências diretas disso, a diminuição das incertezas nas operações e conseqüente agilidade nos ensaios, bem como um controle mais preciso dos procedimentos de ensaios envolvidos.

As mesas que são submetidas a ensaios no LabMov possuem uma variedade grande de dimensões, o que evidencia a necessidade de um projeto específico para tal finalidade. Unindo-se a quantidade de ensaios realizados e a peculiaridade destes, leva à necessidade de uma máquina que possa atender aos requisitos explicitados na norma e ao mesmo tempo atender às exigências do mercado. Através da experiência adquirida nos ensaios realizados no LabMov, se conhece as solicitações a que são submetidas as máquinas desse tipo de ensaio, são registradas falhas e defeitos que ocorrem no uso diário e estes fornecem indicativo do caminho a ser seguido na resolução dos problemas.

Portanto o presente trabalho pretende projetar e simular os vários elementos da máquina existente para ensaio em mesas que foi construída no Laboratório de Ensaio em Móveis da Universidade de Brasília. O projeto vai resultar a necessidade de otimização dos ensaios em mesas do LabMov, sendo fundamentado sob a Norma ABNT NBR 13966:2008. Pretende tratar, em primeira instância, do dimensionamento e da seleção de componentes substitutos para a máquina de ensaios horizontais existente. Irá verificar se os componentes atendem a rigidez adequada para o ensaio, irá ainda verificar a necessidade de aumentar a rigidez, modificando a geometria e a espessura dos elementos de máquina. Terá como objetivo adjunto, projetar um novo dispositivo para ensaios de cargas verticais estáticas e dinâmicas que será um complemento para atender as exigências da referida norma. 


\section{BASE TEÓRICA}

\section{$2.1 \quad$ NORMA REGULAMENTADORA}

Diante da tarefa de projetar uma máquina capaz de realizar ensaios em mesas com vários tamanhos e formas, depara-se com a necessidade de uma padronização das dimensões e características das mesas, bem como os tipos e intensidades de esforços a que as mesas serão submetidas. A padronização das dimensões, além de função ergonômica, faz-se necessária para a determinação das dimensões da própria máquina, pois esta deve contemplar todo o intervalo de tamanhos de mesas.

A Norma ABNT NBR 13966:2008 intitulada "Móveis para escritório - Mesas - Classificação, características físicas e dimensionais, requisitos e métodos de ensaio" é a referência normativa para a elaboração deste projeto, determinando quais ensaios devem ser realizados e à quais solicitações as mesas serão submetidas, além de fornecer as dimensões padrões que as mesas devem possuir, considerando mesas de trabalho e de reunião.

\subsubsection{Requisitos Dimensionais Para Mesas de Trabalho}

As dimensões que constam na Norma ABNT NBR 13966:2008 visam atender a maioria dos usuários dos móveis, e é com base nestas dimensões que a máquina de ensaios deve ser projetada. A Norma possui uma tabela com as dimensões limites em relação a toda a concepção das mesas de escritório.

As dimensões que interessam para o projeto da máquina e que são fornecidas pela Norma, são as larguras e alturas, limitando as dimensões de operação. Ainda que as dimensões sejam exatamente definidas, a máquina terá uma folga de operação com o objetivo principal de facilitar o manejo. A Norma não contempla dimensões máximas, exceto altura do tampo, contudo, serão adotadas empiricamente, com base no histórico de mesas que foram ensaiadas no LabMov.

A referida norma não determina qual comprimento máximo uma mesa de escritório (de reunião ou de trabalho) deve possuir, desta forma será adotado um comprimento máximo de $6000 \mathrm{~mm}$ como limite de projeto da máquina, considerando que nos histórico de ensaios do laboratório houve um caso de uma mesa com essas dimensões. A máquina terá que estar apta a realizar os seguintes ensaios:
a) Estabilidade;
b) Resistência sob aplicação de força horizontal;
c) Resistência sob aplicação de força vertical;
d) Fadiga sob aplicação de força horizontal;
e) Fadiga sob aplicação de força vertical; 
Tabela 1 - Dimensões determinantes (ABNT NBR 13966:2008).

\begin{tabular}{|l|c|c|}
\hline Nome da variável & \multicolumn{2}{|c|}{ Valor } \\
\cline { 2 - 3 } & mínimo & máximo \\
\hline Largura da mesa de trabalho & 800 & --- \\
\hline Largura da mesa de reunião & 1000 & --- \\
\hline Largura livre para as pernas & 600 & --- \\
\hline Profundidade da mesa de trabalho & 600 & --- \\
\hline Profundidade da mesa de reunião & 800 & --- \\
\hline Profundidade da mesa ou conexão usada em microcomputador & 750 & --- \\
\hline Profundidade livre para joelhos & 450 & --- \\
\hline Profundidade livre para os pés & 570 & --- \\
\hline Profundidade livre para as coxas & 200 & \\
\hline Altura da mesa de trabalho e de reunião & 720 & 750 \\
\hline Altura livre sob o tampo & 660 & \\
\hline Altura livre sob as coxas & 620 & \\
\hline Altura livre para os joelhos & 550 & \\
\hline Altura livre para os pés & 120 & \\
\hline Diâmetro da mesa & 800 & --- \\
\hline Raio da borda de contato com o usuário & 2,5 & --- \\
\hline Nota Para mesas com regulagem, as alturas mínimas podem exceder estes limites, desde que \\
contemplem o intervalo indicado. & & \\
\hline
\end{tabular}

\subsubsection{Descrição dos Ensaios}

\section{a. Ensaio de Estabilidade}

O ensaio de estabilidade tem como objetivo verificar a resistência ao tombamento da mesa, sob aplicação de uma carga vertical com intensidade de $750 \mathrm{~N}$ a $50 \mathrm{~mm}$ da borda, na lateral mais suscetível ao tombamento.

A Figura (2.1) abaixo mostra em detalhe este ensaio realizado na máquina universal do LabMov, com travamento dos pés no piso. Note que a mesa, quando possui gavetas, essas devem estar abertas e carregadas, com uma carga variável dependendo das dimensões das gavetas, a ser definida pela fórmula: 


$$
M(k g)=\frac{l}{330} \times \frac{L}{50} \times \frac{h}{300} \times 2,5
$$

De forma que:

$l$ distância entre as laterais das gavetas;

$L \quad$ distância entre o painel (tampo) frontal e o posterior;

$h \quad$ altura livre.
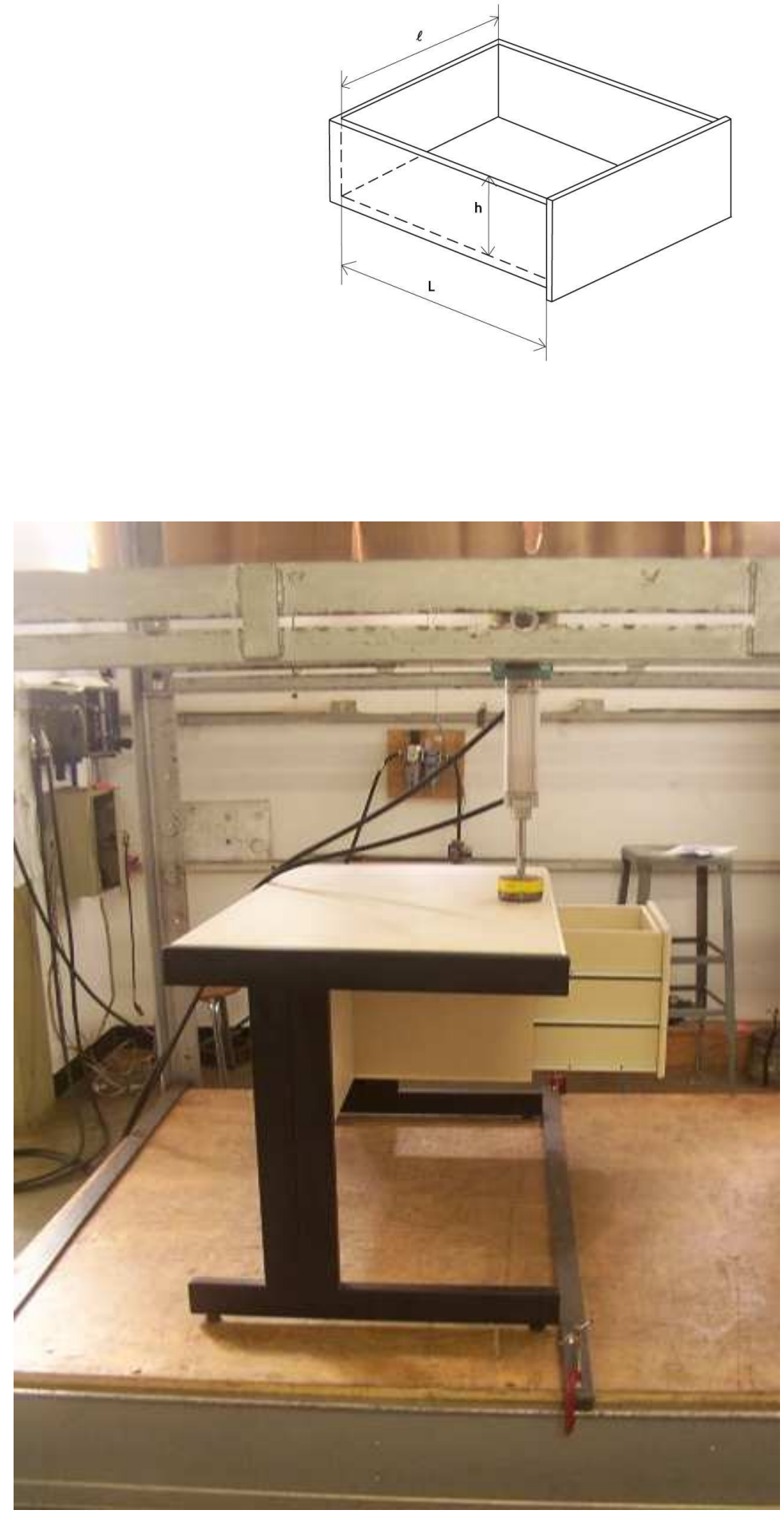

Figura 2.1. Ensaio de estabilidade sob aplicação de carga vertical. (LabMov) 


\section{b. Resistência sob aplicação de força horizontal}

Esse ensaio visa simular situações em que a mesa é puxada ou empurrada. As pernas da mesa devem ser travadas na lateral mais estreita e em seguida aplicada alternadamente uma carga de $450 \mathrm{~N}$ de cada lado da mesa. Esse procedimento deve ser executado 10 vezes mantendo a carga por $10 \mathrm{~s}$. A Figura (2.3) ilustra uma mesa preparada para ensaios horizontais.

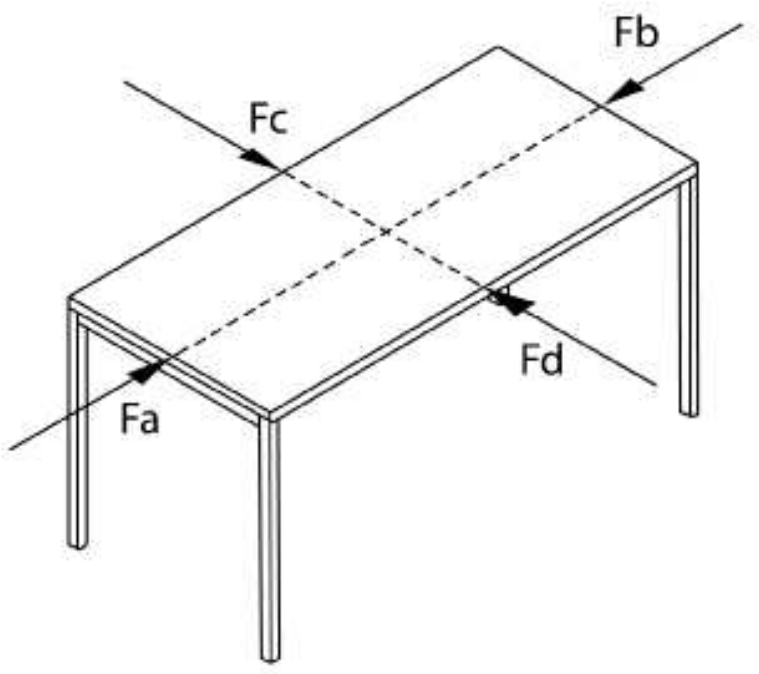

Figura 2.2. Posição de aplicação de cargas para ensaio de resistência (LabMov).

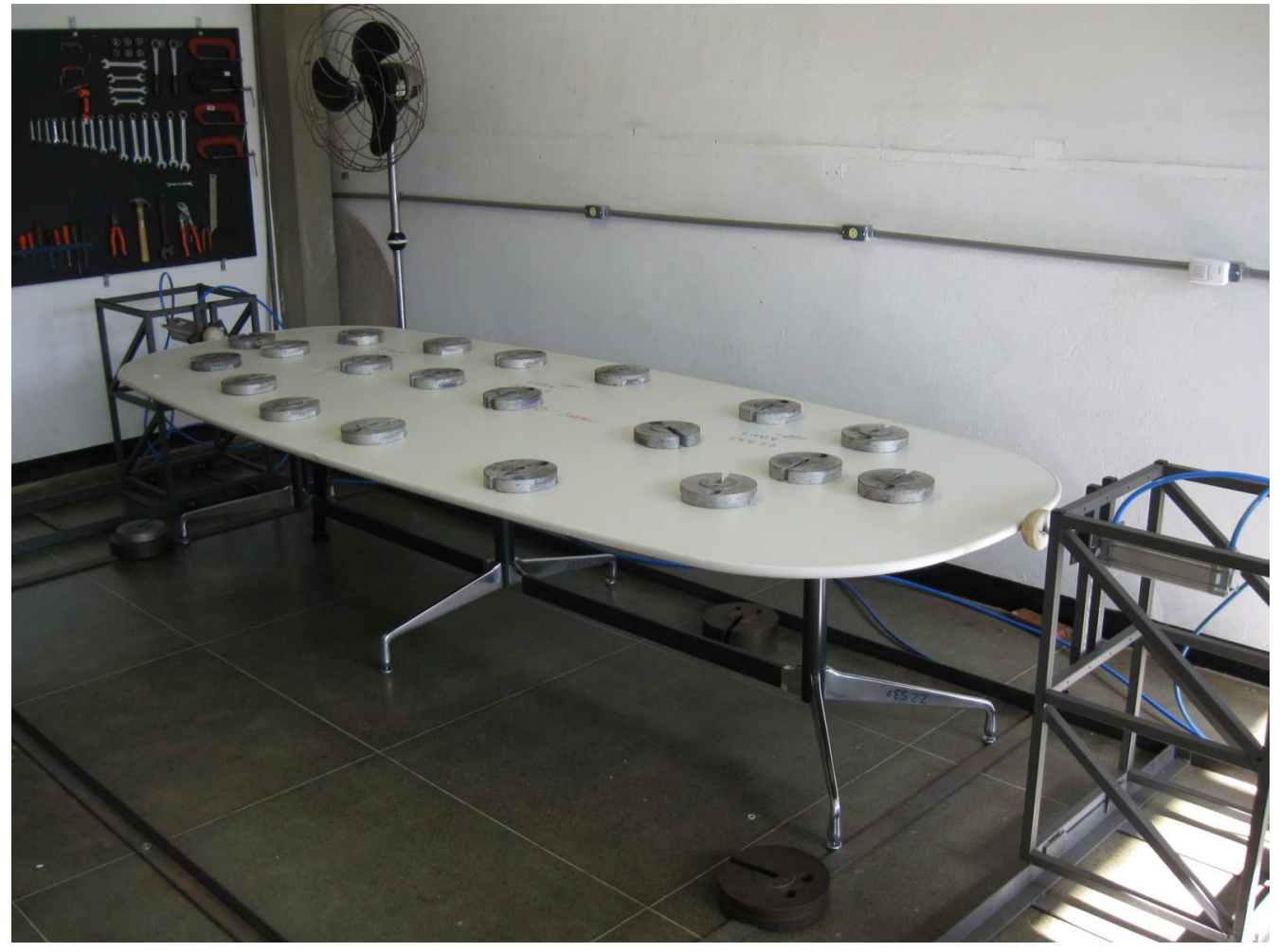

Figura 2.3. Mesa preparada para ensaios horizontais. (LabMov) 


\section{c. Resistência sob aplicação de força vertical}

Nesse ensaio é aplicada uma carga de $1000 \mathrm{~N}$ a 100 mm das bordas e em qualquer ponto passível de falha, durante $10 \mathrm{~s}$ e repetida por 10 vezes. Esse ensaio visa simular uma carga pontual eventual. Os pontos de aplicação podem ser observados na Figura (2.4).

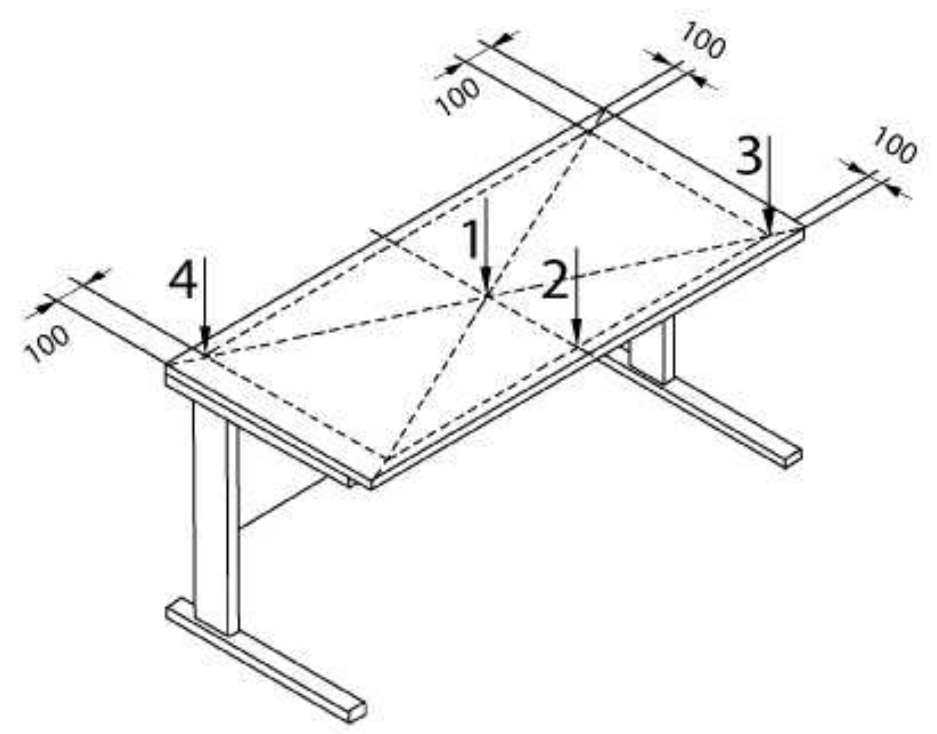

Figura 2.4. Pontos de aplicação de carga para ensaio de resistência vertical. (LabMov)

\section{d. Fadiga sob aplicação de carga horizontal}

Esse ensaio visa verificar a durabilidade da mesa simulando ciclos do dia a dia, como o abrir e fechar de gavetas. A mesa deve ser carregada de forma uniforme com uma massa de $100 \mathrm{~kg}$ e posteriormente aplica-se uma força alternada de $300 \mathrm{~N}$ a $50 \mathrm{~mm}$ da borda da mesa, o carregamento deve ser executado por 5000 ciclos.

\section{e. Fadiga sob aplicação de carga vertical}

Uma carga de $400 \mathrm{~N}$ deve ser aplicada sob a superfície de trabalho da mesa a $100 \mathrm{~mm}$ da borda, o ponto deve ser escolhido de forma que haja maior probabilidade de deformação. O carregamento deve ser executado em 10000 ciclos. A Figura (2.5) ilustra uma mesa sendo ensaiada. 


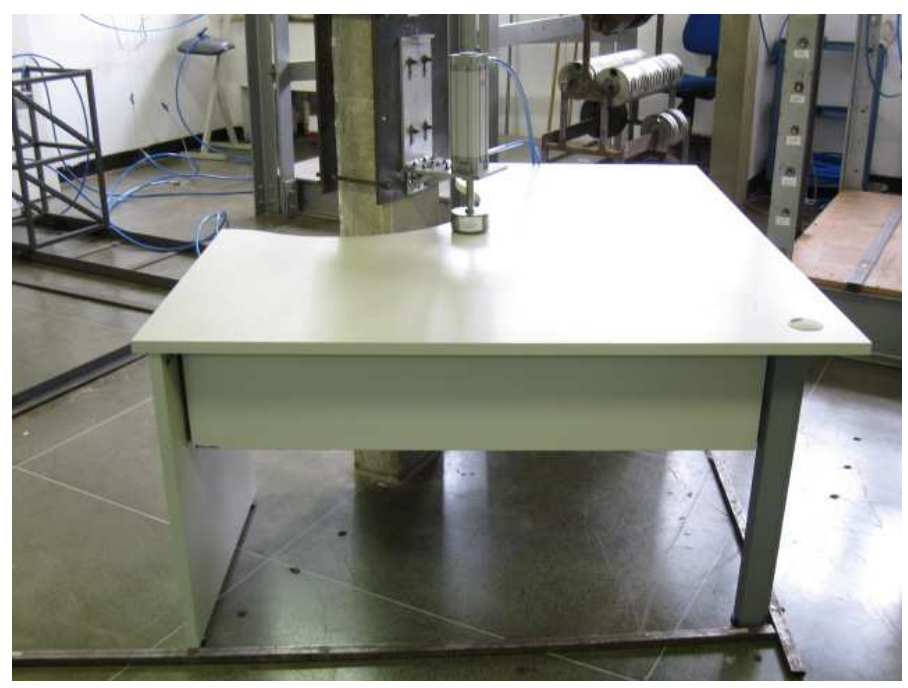

Figura 2.5. Resistência e fadiga sob carga vertical.

\subsubsection{Parâmetros de Projeto}

Os tipos de ensaio brevemente descritos anteriormente, constam na Norma ABNT NBR 13966:2008 e servem de base para determinar as solicitações que serão exigidas da máquina. As tabelas abaixo fornecem um resumo dos limites de operação da máquina.

Tabela 2 - Forças limites.

\begin{tabular}{|l|c|}
\hline Força máxima horizontal & $450 \mathrm{~N}$ \\
\hline Força máxima vertical & $1000 \mathrm{~N}$ \\
\hline
\end{tabular}

Tabela 3 - Dimensões limítes estabelecidas na norma ou assumidas.

\begin{tabular}{|l|c|}
\hline Altura máxima & $750 \mathrm{~mm}$ \\
\hline Largura mínima & $1000 \mathrm{~mm}$ \\
\hline Comprimento máximo & $6000 \mathrm{~mm}$ \\
\hline
\end{tabular}

A máquina terá as seguintes dimensões:

Tabela 4 - Dimensões da máquina.

\begin{tabular}{|l|c|}
\hline Altura máxima de ensaio & $800 \mathrm{~mm}$ \\
\hline Largura máxima de ensaio & $2000 \mathrm{~mm}$ \\
\hline $\begin{array}{l}\text { Comprimento máximo de } \\
\text { ensaio }\end{array}$ & $6000 \mathrm{~mm}$ \\
\hline
\end{tabular}




\subsection{SISTEMA PNEUMÁTICO}

Atualmente, o controle do ar suplanta os melhores graus da eficiência, executando operações sem fadiga, economizando tempo, ferramentas e materiais, além de fornecer segurança ao trabalho.

Um sistema de automação industrial é constituído de três tipos de elementos:

- Sensores

- Controladores (comando e regulação)

- Atuadores (acionamento)

Cada um desses elementos pode ser implementado usando-se três tipos de energia:

- Pneumática

- Hidráulica

- Elétrica

A utilização de sensores e motores elétricos abrange uma grande gama de aplicações, no entanto existem situações em que somente a energia hidráulica e pneumática oferece uma solução mais eficiente e de baixo custo. Além disso, em algumas aplicações não é permitido a ocorrência de faíscas elétricas (pintura de automóvel, mina de carvão, fábrica de armamentos, etc), não sendo interessante nesse caso utilizar motores elétricos, por exemplo.

Assim, atuadores hidráulicos são utilizados quando cargas da ordem de até centenas de toneladas estão envolvidas, como por exemplo em tratores, guindastes, ou quando se deseja uma alta precisão de posicionamento, como em máquinas de usinagem de precisão e micro-manipuladores, que em geral não podem ser obtidos com motores e sistemas elétricos.

Atuadores pneumáticos são utilizados quando estão envolvidas cargas da ordem de até uma tonelada onde se deseja movimentos de duas posições (início e fim) limitadas por batentes mecânicos, como em máquinas de fixação ou transporte de peças, ou quando se deseja altas rotações (milhares de r.p.m.), como no caso de fresadoras pneumáticas ou brocas de dentista.

Eventualmente encontraremos equipamentos em que ocorre uma combinação do uso das energias acima. Por exemplo, em sistemas eletropneumáticos temos atuadores pneumáticos acionados por controladores elétricos ou eletrônicos, bem como, sensores elétricos ou pneumáticos. O mesmo ocorre em sistemas eletro-hidráulicos.

Pneumática é o ramo da engenharia que estuda a aplicação do ar comprimido para a tecnologia de acionamento e comando. No século XIX, surgiram as primeiras máquinas pneumáticas complexas, as locomotivas e perfuratrizes (nas minas de carvão). Na verdade, essas máquinas utilizavam vapor superaquecido e não ar comprimido propriamente dito, no entanto os princípios envolvidos no funcionamento são idênticos. 
No entanto, foi no século XX, que a pneumática passou a ser aplicada na automação industrial e se desenvolveu ao ponto que é conhecida hoje. Atualmente existem várias aplicações da pneumática no meio industrial e mesmo na nossa vida diária. Entre alguns exemplos de aplicações atuais de pneumática podemos citar:

- Prensas pneumáticas;

- Dispositivos de fixação de peças em máquinas ferramenta e esteiras;

- Acionamento de portas de um ônibus urbano ou dos trens do metrô;

- Sistemas automatizados para alimentação de peças;

- Robôs industriais para aplicações que não exijam posicionamento preciso;

- Freios de caminhão;

- Parafusadeiras e lixadeiras;

- Broca de dentista;

- Pistola de pintura;

- Correio pneumático.

Assim, como no caso dos motores elétricos, o sistema de acionamento pneumático é constituído pelos elementos mostrados na figura 2.6.

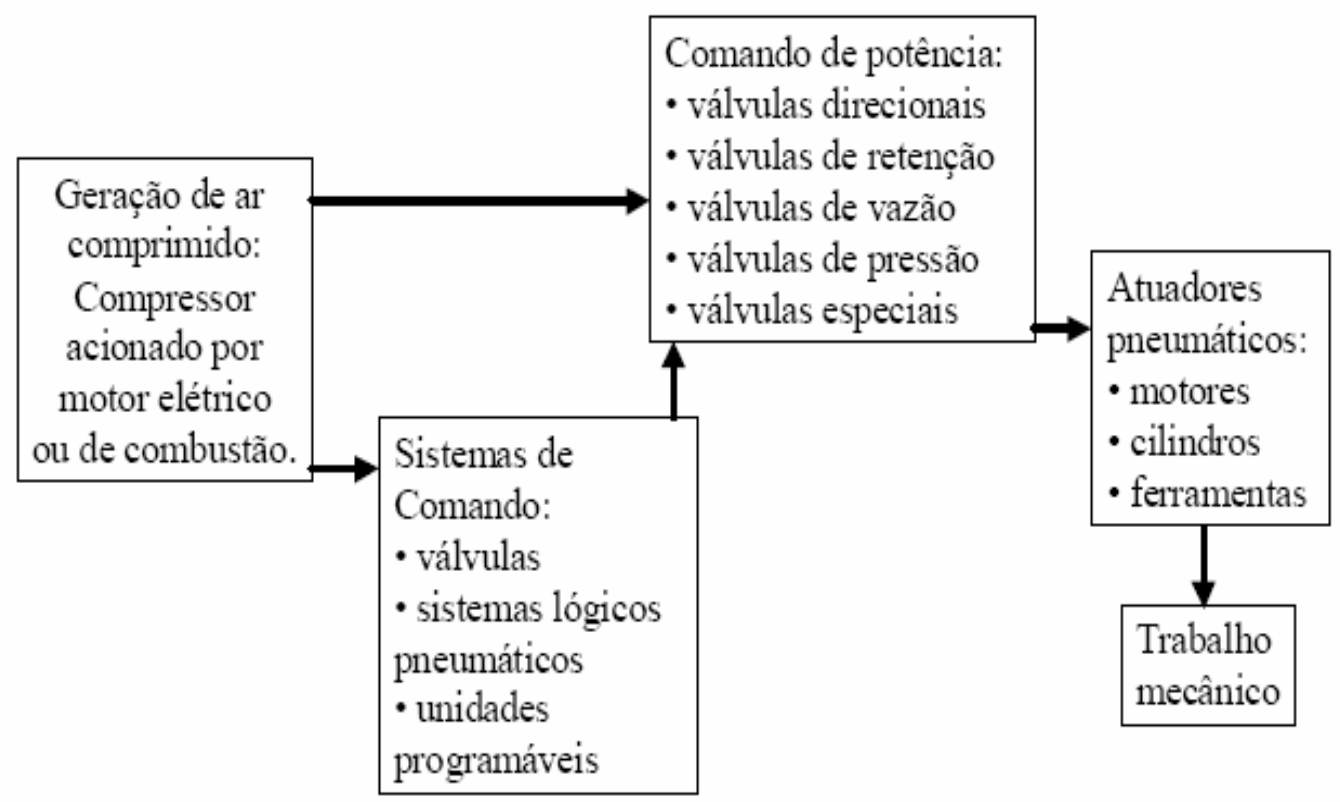

Figura 2.6. Esquema de um sistema pneumático completo (Parker).

Os sistemas de comando são os responsáveis por controlar o atuador pneumático mediante a informação dos sensores. Pode consistir num microcomputador, por exemplo. Já o sistema de 
comando de potência converte os sinais recebidos do sistema de comando em sinais de níveis de energia coerente para acionar os atuadores.

\subsubsection{Características dos Sistemas Pneumáticos}

Analisando as características do ar comprimido comentadas anteriormente podemos entender as caraterísticas dos sistemas pneumáticos.

\section{Vantagens da implantação:}

1) - Incremento da produção com investimento relativamente pequeno.

2) - Redução dos custos operacionais. A rapidez nos movimentos pneumáticos e a libertação do operário (homem) de operações repetitivas possibilitam o aumento do ritmo de trabalho, aumento de produtividade e, portanto, um menor custo operacional.

3) - Robustez dos componentes pneumáticos. A robustez inerente aos controles pneumáticos torna-os relativamente insensíveis a vibrações e golpes, permitindo que ações mecânicas do próprio processo sirvam de sinal para as diversas seqüências de operação. São de fácil manutenção.

4) - Facilidade de implantação. Pequenas modificações nas máquinas convencionais, aliadas à disponibilidade de ar comprimido, são os requisitos necessários para implantação dos controles pneumáticos.

5) - Resistência a ambientes hostis. Poeira, atmosfera corrosiva, oscilações de temperatura, umidade, submersão em líquidos, raramente prejudicam os componentes pneumáticos, quando projetados para essa finalidade.

6) - Simplicidade de manipulação. Os controles pneumáticos não necessitam de operários extremamente especializados para sua manipulação.

7) - Segurança. Como os equipamentos pneumáticos envolvem sempre pressões moderadas, tornam-se seguros contra possíveis acidentes, quer no pessoal, quer no próprio equipamento, além de evitarem problemas de explosão.

8) - Redução do número de acidentes. A fadiga é um dos principais fatores que favorecem acidentes; a implantação de controles pneumáticos reduz sua incidência (liberação de operações repetitivas).

\section{Limitações:}

1) - $\mathrm{O}$ ar comprimido necessita de uma boa preparação para realizar o trabalho proposto: remoção de impurezas, eliminação de umidade para evitar corrosão nos equipamentos, engates ou travamentos e maiores desgastes nas partes móveis do sistema. 
2) - Os componentes pneumáticos são normalmente projetados e utilizados a uma pressão máxima de 1723,6 kPa. Portanto, as forças envolvidas são pequenas se comparadas a outros sistemas. Assim, não é conveniente o uso de controles pneumáticos em operação de extrusão de metais. Provavelmente, o seu uso é vantajoso para recolher ou transportar as barras extrudadas.

3) - Velocidades muito baixas são difíceis de ser obtidas com o ar comprimido devido às suas propriedades físicas. Neste caso, recorre-se a sistemas mistos (hidráulicos e pneumáticos).

4) - O ar é um fluido altamente compressível, portanto, é impossível se obterem paradas intermediárias e velocidades uniformes. $\mathrm{O}$ ar comprimido é um poluidor sonoro quando são efetuadas exaustões para a atmosfera. Esta poluição pode ser evitada com o uso de silenciadores nos orifícios de escape.

5) - O ar apresenta também uma baixa viscosidade. A viscosidade mede a facilidade com que um fluido (gás ou líquido) escoa. Se um fluido tem baixa viscosidade implica que ele pode escoar por pequenos oríficios e portanto a chance de ocorrer vazamentos é muito grande. Assim, vazamentos de ar em linhas pneumáticas são muito comuns.

\subsubsection{Válvulas Pneumáticas}

Para desenvolverem suas ações produtivas, os cilindros pneumáticos componentes para máquinas de produção, devem ser alimentados ou descarregados convenientemente no instante em que desejarmos ou de conformidade com o sistema programado. Portanto, de acordo com seu tipo, as válvulas servem para orientar os fluxos de ar, impor bloqueios, controlar suas intensidades de vazão ou pressão. Para facilidade de estudo, as válvulas pneumáticas foram classificadas nos seguintes grupos:

- Válvulas de Controle Direcional

- Válvulas de Bloqueio (Anti-Retorno)

- Válvulas de Controle de Fluxo

- Válvulas de Controle de Pressão

A figura seguinte ilustra um esquema envolvendo um cilindro, uma válvula de fluxo e uma válvula direcional. 


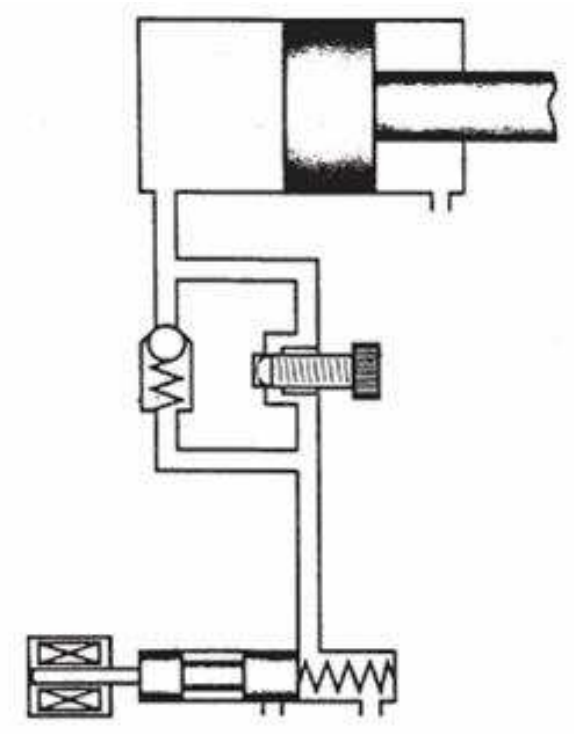

Figura 2.7. Válvula de fluxo e válvula direcional. (Silva).

\subsubsection{Regulagem de Pressão}

Normalmente um sistema de produção de ar comprimido atende à demanda de ar para vários equipamentos pneumáticos. Em todos estes equipamentos está atuando a mesma pressão. Isso nem sempre é possível, pois, se estivermos atuando um elemento pneumático com pressão maior do que realmente necessita, estaremos consumindo mais energia que a necessária.

Por outro lado, um grande número de equipamentos operando simultaneamente num determinado intervalo de tempo faz com que a pressão caia de forma mais acentuada, devido ao pico de consumo ocorrido. Estes inconvenientes são evitados usando-se a Válvula Reguladora de Pressão, ou simplesmente o Regulador de Pressão, que tem por função:

- Compensar automaticamente o volume de ar requerido pelos equipamentos pneumáticos.

- Manter constante a pressão de trabalho (pressão secundária), independente das flutuações da pressão na entrada (pressão primária) quando acima do valor regulado. A pressão primária deve ser sempre superior à pressão secundária, independente dos picos.

- Funcionar como válvula de segurança.

A figura a seguir descreve uma válvula de segurança juntamente com o seu símbolo. 


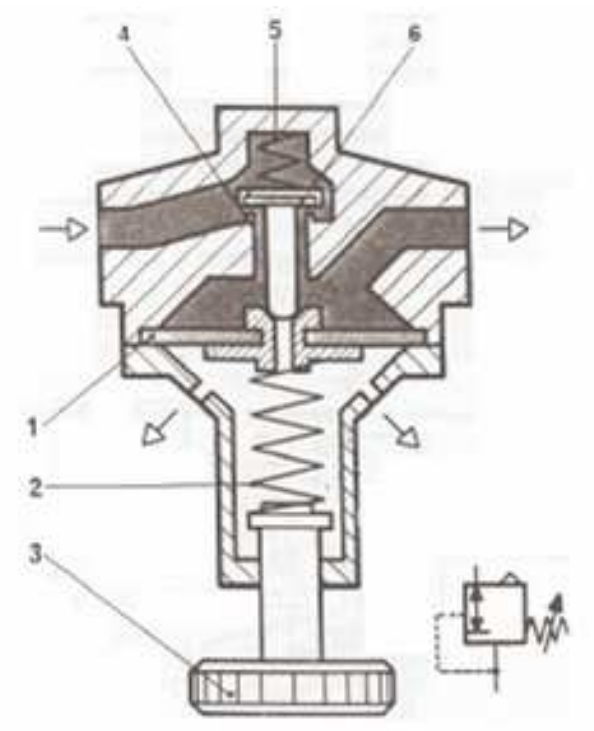

Figura 2.8. Válvula de controle de pressão (Silva).

\subsubsection{Atuadores Pneumáticos}

É necessário dispor de um dispositivo que converta em trabalho a energia contida no ar comprimido. Os conversores de energia são os dispositivos utilizados para tal fim. Num circuito qualquer, o conversor é ligado mecanicamente à carga. Assim, ao ser influenciado pelo ar comprimido, sua energia é convertida em força ou torque, que é transferido para a carga.

As principais características dos atuadores pneumáticos são:

- Apresentam baixa rigidez devido à compressibilidade do ar;

- Não há precisão na parada em posições intermediárias;

- Apresentam uma favorável relação peso/potência;

- Dimensões reduzidas;

- Segurança à sobrecarga;

- Facilidade de inversão;

- Proteção à explosão.

Os conversores de energia, por sua vez, estão divididos em três grupos:

- Os que produzem movimentos lineares

- Os que produzem movimentos rotativos

- Os que produzem movimentos oscilantes 


\section{Lineares}

São constituídos de componentes que convertem a energia pneumática em movimento linear ou angular. São representados pelos Cilindros Pneumáticos. Dependendo da natureza dos movimentos, velocidade, força, curso, haverá um mais adequado para a função.

\section{Rotativos}

Convertem energia pneumática em energia mecânica, através de momento torsor contínuo.

\section{Oscilantes}

Convertem energia pneumática em energia mecânica, através de momento torsor limitado por um determinado número de graus.

\subsubsection{Cilindros}

No mercado os cilindros estão disponíveis em diversas configurações, com diversas opções de combinações das roscas de alimentação e canais para instalação dos sensores. Os principais fabricantes de cilindros fornecem um elenco amplo desses equipamentos de modo a atender uma extensa gama de aplicações. As séries são compostas por cilindros com 10 diferentes diâmetros, de 12 a 100 mm, com cursos de $5 \mathrm{~mm}$ a $500 \mathrm{~mm}$ (PARKER TRAINING). São fornecidos pré-lubrificados, portanto, normalmente não necessitam de lubrificação adicional, mas, caso seja aplicada, esta deverá ser mantida em regime contínuo através de um lubrificador de linha.

Os canais internos do tubo permitem a comunicação entre os cabeçotes, transferindo ar para as duas extremidades do cilindro. As posições das roscas de alimentação podem ser especificadas de diferentes maneiras, atendendo às diversas aplicações e/ou necessidades de cada cliente.

Como opções tem-se, radial na tampa dianteira, radial ou axial na tampa traseira, alimentação somente na tampa traseira ou em ambas. A flexibilidade de opções das roscas de alimentação, juntamente com uma escolha do tipo de montagem, garante que esta série pode ser usada em várias aplicações. É especialmente indicado nas aplicações onde o espaço é limitado, como por exemplo, nas indústrias de embalagens, eletrônicos e outros.

Além da versão básica, como haste em aço inox, êmbolo magnético e amortecimento fixo traseiro, a série inclui outras opções, tais como: guias externas, haste passante, roscas macho e fêmea nas hastes. Os canais integrados ao corpo do tubo garantem uma fácil e rápida instalação dos sensores, não prejudicando o design externo do cilindro. O fato desses canais serem duplos permite a instalação agrupada dos sensores. Para os cilindros de $\varnothing 32 \mathrm{~mm}$ até $100 \mathrm{~mm}$ os orifícios de fixação e os seus acessórios estão de acordo com a Norma ISO 6431, VDMA 24562 e AFNOR (PARKER TRAINING). Os cilindros se diferenciam entre si por detalhes construtivos, em função de suas características de funcionamento e utilização. 
Quanto à complexidade do movimento executado, existem dois tipos de cilindros:

- Simples Efeito ou Simples Ação

- Duplo Efeito ou Dupla Ação, com e sem amortecimento.

Além de outros tipos de construção derivados como:

- Cilindro de Dupla Ação com haste dupla

- Cilindro duplex contínuo (Tandem)

- Cilindro duplex geminado (múltiplas posições)

- Cilindro de impacto

- Cilindro de tração por cabos

\subsubsection{Cilindro de Duplo Efeito ou Dupla Ação}

Quando um cilindro pneumático utiliza ar comprimido para produzir trabalho em ambos os sentidos de movimento (avanço e retorno), diz-se que é um cilindro de Dupla Ação, o tipo mais comum de utilização. Sua característica principal, pela definição, é o fato de se poder utilizar tanto o avanço quanto o retorno para desenvolvimento de trabalho.

Existe, porém, uma diferença quanto ao esforço desenvolvido: as áreas efetivas de atuação da pressão são diferentes; a área da câmara traseira é maior que a da câmara dianteira, pois nesta há que se levar em conta o diâmetro da haste, que impede a ação do ar sobre toda a área. O ar comprimido é admitido e liberado alternadamente por dois orifícios existentes nos cabeçotes, um no traseiro e outro no dianteiro que, agindo sobre o êmbolo, provocam os movimentos de avanço e retorno. Quando uma câmara está admitindo ar a outra está em comunicação com a atmosfera.

Esta operação é mantida até o momento de inversão da válvula de comando; alternando a admissão do ar nas câmaras, Esta operação é mantida até o momento de inversão da válvula de comando; alternando a admissão do ar nas câmaras, o pistão se desloca em sentido contrário. 


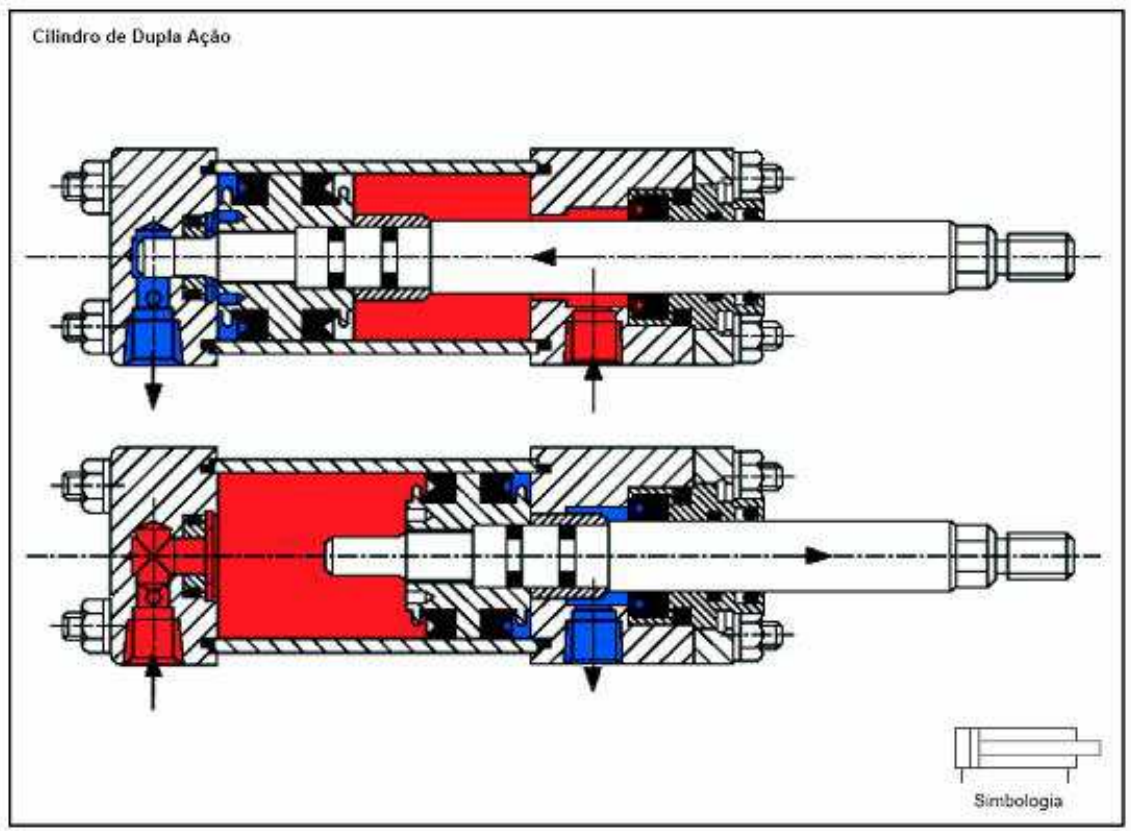

Figura 2.9. Cilindro de dupla ação. (Parker training).

\subsection{SISTEMA PNEUMÁTICO DO LABMOV}

O sistema pneumático do LabMov é um sistema convencional, com o controle realizado por um Módulo Lógico Programável. Existem dois painéis de controle, que são usados para diferentes tipos de ensaios, além dos realizados em mesas, como também em cadeiras, estações de trabalho ou armários.

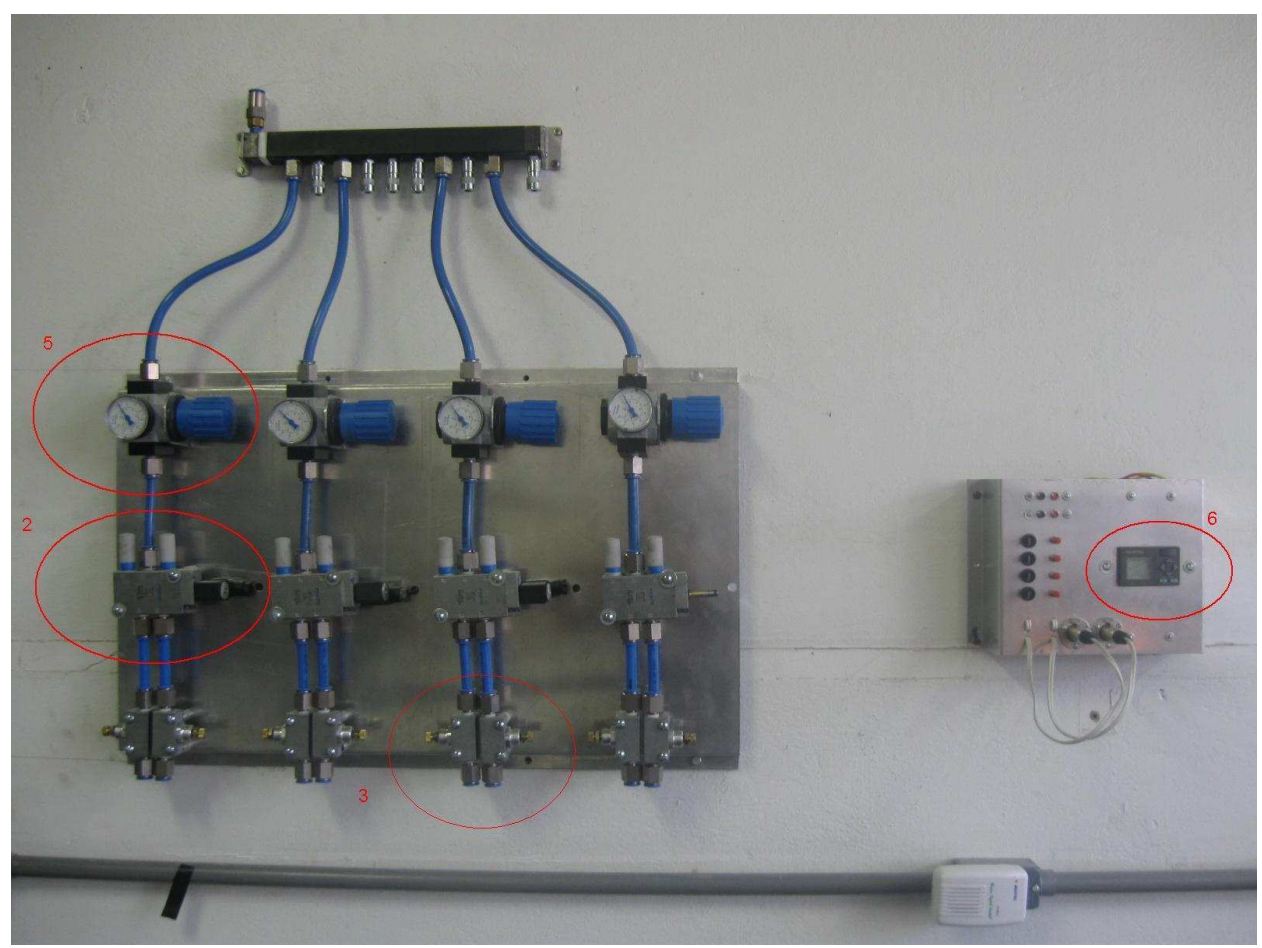

Figura 2.10. Sistema de controle dos cilindros. 
Na tabela a seguir estão discriminados alguns dos equipamentos:

Tabela 5 - Detalhamento dos equipamentos pneumáticos usados no LabMov.

\begin{tabular}{|c|c|c|c|}
\hline & Equipamento & Especificação & Função \\
\hline 1 & $\begin{array}{l}\text { Cilindro pneumático de } \\
\text { dupla ação; }\end{array}$ & $\begin{array}{l}\text { DNC }-63- \\
160\end{array}$ & $\begin{array}{l}\text { Atuador que aplica as cargas nos } \\
\text { ensaios; }\end{array}$ \\
\hline 2 & $\begin{array}{l}\text { Válvula pneumática } \\
\text { solenóide-mola ; }\end{array}$ & JMFH - 5-1/4 & $\begin{array}{l}\text { Direciona o avanço e recuo do } \\
\text { cilindro; }\end{array}$ \\
\hline 3 & $\begin{array}{l}\text { Válvula reguladora de } \\
\text { fluxo; }\end{array}$ & $\mathrm{GR}-1 / 8$ & $\begin{array}{l}\text { Restringe a passagem do ar, } \\
\text { controlando a velocidade de avanço; }\end{array}$ \\
\hline 4 & Lubrificador & $\begin{array}{l}\text { LOE }-\mathrm{D}- \\
\text { MINI }\end{array}$ & Adiciona lubrificante a linha; \\
\hline 5 & $\begin{array}{l}\text { Válvula reguladora de } \\
\text { pressão }\end{array}$ & LRP $-1 / 4-10$ & $\begin{array}{l}\text { Permite a regulagem fina da } \\
\text { pressão; }\end{array}$ \\
\hline 6 & $\begin{array}{c}\text { Módulo } \\
\text { Programável }\end{array}$ & LOGO! & $\begin{array}{l}\text { Recebe programação dos } \\
\text { ensaios, firmando duração, intervalo } \\
\text { e quantidade de ciclos. }\end{array}$ \\
\hline
\end{tabular}

A Figura (2.10) mostra os componentes de controle do sistema pneumático. Este é um dos três conjuntos que controlam os cilindros nos diversos ensaios do LabMov.

Com o uso do Módulo Lógico Programável se determina os ciclos que serão aplicados a cada caso de ensaio. É o MLP que envia sinais para os solenóides das válvulas direcionais, de forma que os atuadores avançam ou recuam em tempos programados e permanecem aplicando a carga, de acordo com o posicionamento das válvulas.

As cargas são especificadas de acordo com a Norma ABNT NBR 13966:2008, e a intensidade dessas cargas no ensaio, é determinada com o auxílio de uma célula de carga baseada em um extensômetro, sendo posicionada no atuador enquanto a pressão é variada, com o auxílio de uma válvula reguladora de pressão, com isto se obtém a força necessária para cada ensaio.

Desta forma, foi elaborada uma tabela com as forças e suas respectivas pressões, de maneira que não se faz necessário repetir o procedimento, anteriormente descrito, para cada ensaio. O tempo de avanço do atuador depende da regulagem da válvula reguladora de fluxo, podendo ser ajustada conforme a situação. 


\subsection{SOFTWARES DE MODELAMENTO E ELEMENTOS FINITOS}

O software selecionado para a modelagem foi o SolidWorks ${ }^{\circledR}$, software CAD usado em modelagem 3D que é apropriado principalmente em casos em que se trabalha com componentes e montagens. O SolidWorks ${ }^{\circledR}$ permite modificações rápidas e fornece uma visualização tridimensional realista. O programa permite ainda, mostrar as relações reais de interação entre os vários elementos de uma máquina, através da montagem de um protótipo virtual.

O conceito principal do programa é a criação de sólidos a partir de formas geométricas elementares, criando conexões entre vértices e curvas. As peças, depois de criadas, podem ser conectadas a fim de se montar um protótipo virtual, onde existe a possibilidade de estabelecer relações entre as peças da forma como elas teriam na realidade, como paralelismo e concentricidade entre planos e furos dos componentes. As simulações, considerando todos estas características, são reais e dinâmicas, permitindo uma ilustração muito nítida dos mecanismos e movimentos.

O programa conta ainda com uma série de pacotes integrados que auxiliam em todas as etapas de projeto, como as ferramentas CosmosXpress ${ }^{\circledR}$, CosmosWorks $^{\circledR}$ e CosmosFloXpress, ferramentas estas que permitem fazer simulações de esforços e reações de carregamentos, além de análises de escoamentos entre outros.

O pacote CosmosXpress ${ }^{\circledR}$ integrado a plataforma SolidWorks ${ }^{\circledR}$ é uma ferramenta que permite a análise estrutural de projetos de peças simples, através do Método dos Elementos Finitos (MEF). Com o CosmosXpress ${ }^{\circledR}$ é possível realizar simulações estáticas de cargas, fornecendo como resultados os fatores de segurança, deformações e tensões máximas do projeto. Esta ferramenta foi utilizada nas análises dos elementos deste projeto, fornecendo resultados decisivos para a seleção das estruturas.

O princípio de análise do CosmosXpress ${ }^{\circledR}$ é baseado em engastes e forças aplicados em faces da estrutura. A partir da definição destes engastes e cargas é gerada uma malha no modelo CAD 3D que permite a análise por MEF. 


\section{FORMULAÇÃO DO PROBLEMA}

\subsection{METODOLOGIA}

Ao iniciar um projeto, se faz necessária uma metodologia para estruturar as várias etapas em que consiste, uma organização que deve possibilitar a resolução do problema com maior eficiência. A seguinte sugestão de etapas pode ser aplicada neste caso específico:

1) Identificação das necessidades

2) Pesquisa suporte

3) Definição dos objetivos

4) Especificação das tarefas

5) Análise

6) Projeto

A partir desta lista se pode traçar uma seqüência clara para o projeto.

\subsection{EXPOSIÇÃO DE PROBLEMAS E EXIGÊNCIAS}

A criação desse projeto foi motivada pela necessidade de se produzir uma máquina que realize ensaios em mesas, a fim de agilizar os ensaios realizados no LabMov.

Existe hoje em uso no LabMov uma máquina, projetada no ano de 2008, que realiza ensaios horizontais de fadiga e resistência. No entanto, se faz necessário o projeto de um dispositivo que realize ensaios também verticais, em função da proposta da máquina de realizar ensaios em mesas de até seis metros. Há um dispositivo apto a realizar esses ensaios e é usado para tal, contudo, a dificuldade e o tempo levado para retirar a mesa do local de ensaios horizontais, mostram uma necessidade clara da realização desses ensaios no mesmo local.

Além da necessidade dos ensaios verticais junto aos horizontais, observou-se, durante os testes realizados na máquina, algumas falhas que dificultavam a realização dos ensaios. O problema mais grave encontrado foi a elevada deformação da barra de apoio do carro, principalmente quando o carro era posicionado no meio da barra. A falta de rigidez em uma máquina resulta, na maioria das vezes, em um processo com pouca precisão, no que interfere diretamente na qualidade e confiabilidade do processo.

Entre alguns dos problemas que podem aparecer em consequiência da falta da rigidez está a possibilidade de mascarar a força real aplicada, além de dificultar o posicionamento seguro dos elementos de ensaio junto às mesas. A segurança dos operadores da máquina também é um fator de 
extrema importância e pode ficar comprometida na operação de uma máquina que possua baixa rigidez, principalmente se existir a possibilidade de escapar alguma peça.

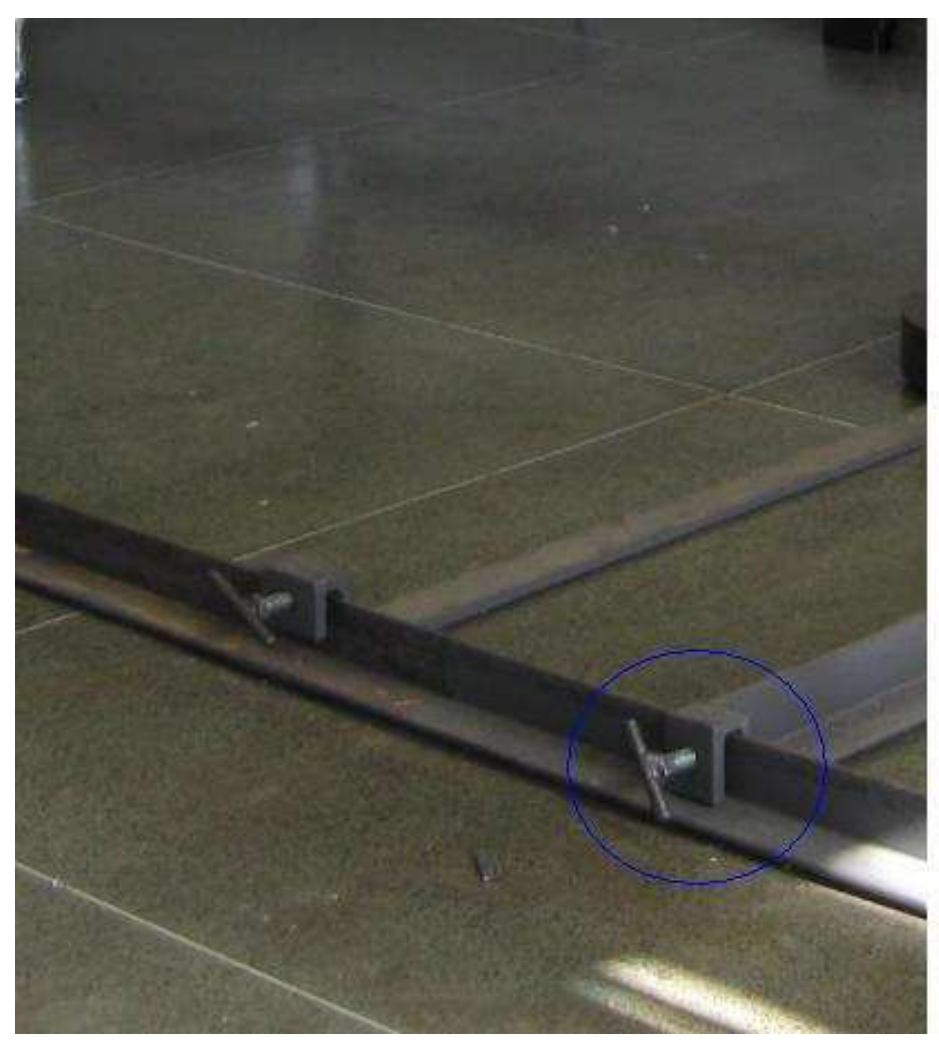

Figura 3.1. Detalhe da pinça de fixação da barra.

Outro problema encontrado foi a fixação em forma de pinça da barra de apoio do carro. Esse tipo de fixação é predisposta ao escape, o que também compromete a qualidade e segurança do serviço. Para se evitar que a fixação escape, uma pré-carga elevada é necessária, acarretando tensões elevadas e possibilidades de falha. A Figura (3.1) mostra a pinça da máquina atual e que será analisada adiante com objetivo de substituição da peça.

Observou-se nos ensaios diários do LabMov fraturas constantes desta pinça, provocando atrasos consideráveis em função da espera para realização de reparos. Como é visto na Figura (3.2), a estrutura na parte de baixo da foto é responsável por sustentar o carro de ensaios verticais, observa-se um filete de solda no topo, o qual indica reparo na estrutura. Essa parte da estrutura se comporta como uma viga em balanço, observando atentamente se nota uma leve flexão, caracterizada pela deformação na solda. A estrutura na parte de cima é de uma de uma peça íntegra, que nunca necessitou de reparos. Note que a máquina estava em repouso no momento da fotografia. 


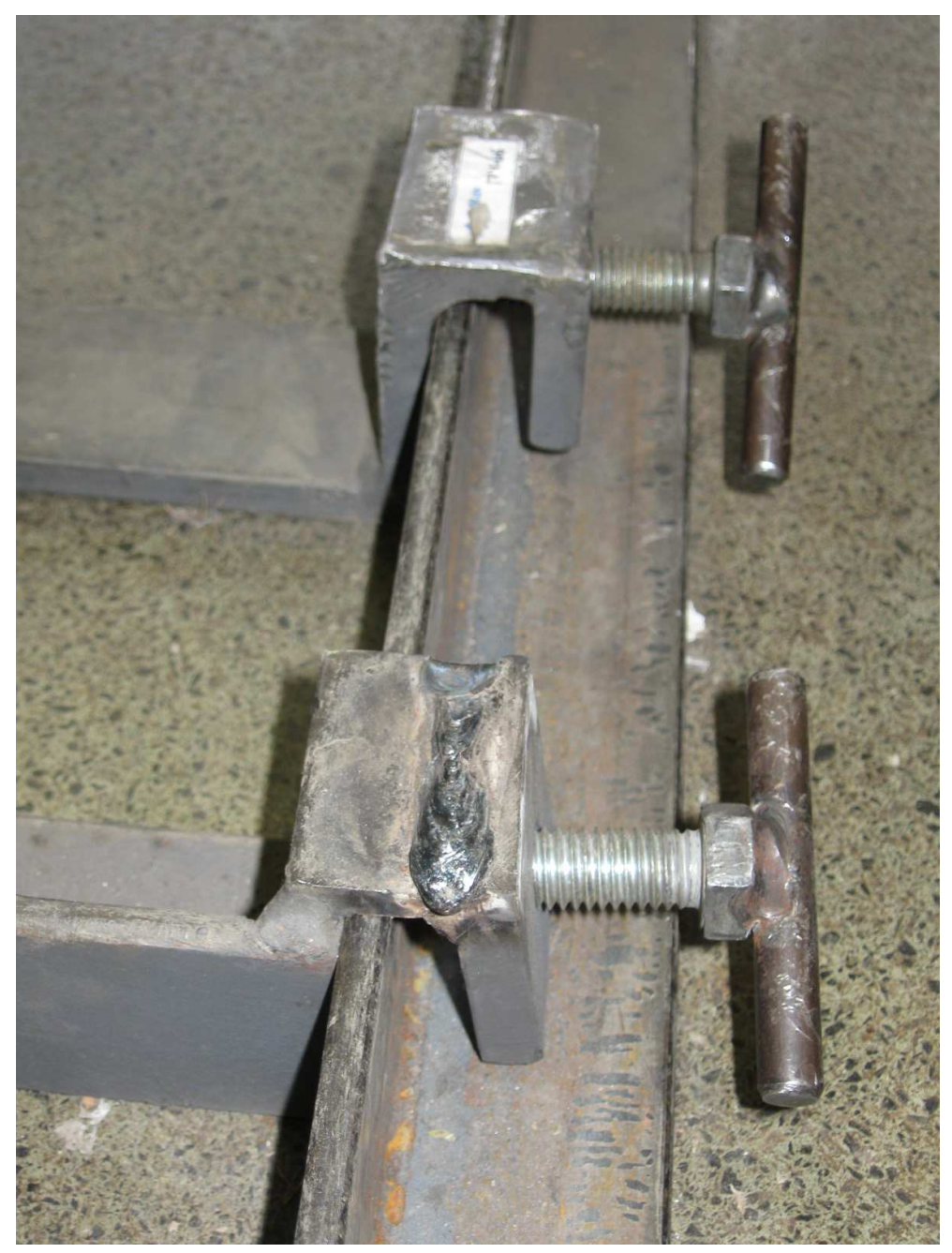

Figura 3.2. Pinça íntegra e pinça reparada, de cima para baixo.

\subsection{SOLUÇÕES PROPOSTAS}

\subsubsection{Máquina de Ensaio Horizontal}

Os pontos mais urgentes a serem analisados são, de fato, a elevada deformação e fratura da pinça de fixação. O acréscimo de rigidez da máquina pode prever várias soluções possíveis, desde adoção de perfil com maior momento de inércia de seção, até a utilização de outro material com diferente módulo de elasticidade. O aço, por ser fácil de encontrar e por possuir preço acessível, é o material mais viável para esse tipo de aplicação. Resta a alternativa referente ao aumento do momento de inércia da seção do perfil a ser utilizado, de forma que se faz necessária a substituição dos componentes que apresentam deformação elevada.

Alguns perfis possuem momento de inércia de secção bastante elevado em relação ao perfil em L utilizado, mas destaca-se o fato deste ainda poder ser utilizado, caso o perfil possua abas e espessura de chapa maiores. No entanto, durante observações feitas no funcionamento da máquina, percebeu-se 
a possibilidade de resolver o problema de fixação através da troca do perfil, trocando a fixação de pinça por um apoio perpendicular à direção de aplicação dos esforços, a Figura (3.4) explicita como ficaria essa fixação.

No mercado existe uma grande variedade de barras com perfis de várias configurações, variam em complexidade de forma e dimensões, o que permite uma análise bastante rica. Os momentos de inércia variam muito mais com a forma do que com a espessura propriamente dita, e como é um dos objetivos resolver o problema de fixação, a possibilidade de adoção de dois perfis em particular devem ser estudadas.

Os perfis em I e em U possuem rigidez elevada e abas no formato concebido para a solução da forma de fixação. O perfil em I possui momento de inércia elevado, e dá mostras de que é uma boa escolha, pesando contra o fato de ser caro. O perfil em U possui momento de inércia similar ao perfil em L, em função das características geométricas.

Através de uma pesquisa no mercado, em empresas do ramo de ferragens para construção, foi verificada uma diferença grande de preço do perfil em I em relação ao perfil em U. O perfil em U é concebido a partir da dobra de uma chapa em aço doce, já o perfil em I é trabalhado a quente e produzido com aço estrutural A36. Dessa forma, o perfil em U parece ser uma escolha apropriada, e será posto a prova em cálculos posteriores.

\subsubsection{Máquina de Ensaio Vertical}

Além da resolução dos problemas apresentados pela máquina em uso no LabMov, outra questão discutida e proposta foi o projeto de um dispositivo para aplicação de cargas verticais, com intuito de facilitar o manejo e agilizar os ensaios de mesas. Seguindo a mesma linha e pensando em termos de rigidez, algumas soluções podem ser sugeridas.

A estrutura que sustenta o pistão pneumático deve ter rigidez considerável, compatível ou maior do que os outros componentes, em função de solicitações superiores.

Considerando o comprimento das mesas, além da necessidade de posicionamento do pistão em qualquer ponto da mesa, depara-se com a necessidade de uma movimentação em trilhos, a fim de facilitar a preparação da máquina para os ensaios. Com isso, um dispositivo em forma de arco parece suprir as exigências dimensionais, com rolamentos nas extremidades dos arcos que permitam o deslizamento ao longo da máquina. As Figuras (3.3) e (3.4) mostram uma visão geral da nova máquina e uma vista explodida do dispositivo de ensaio vertical, respectivamente.

A elaboração e projeto da fração da máquina responsável pelos ensaios verticais, devem ser concebidos tendo como base partes pré-existentes, propondo uma treliça, assim como no carro para ensaios horizontais. A escolha baseia-se nas propriedades conhecidas das treliças, como a rigidez elevada em relação ao peso reduzido, e também em fatores estéticos, com interesse em uma aparência 
homogênea. O peso é uma variável de discussão indispensável, pois todo o posicionamento da máquina para os ensaios será feito manualmente.

O carro que sustenta o dispositivo de aplicação vertical de cargas também foi analisado utilizando o pacote COSMOSXpress. O carro se apóia nas barras laterais através de dois rolamentos, de forma que possui movimento com um grau de liberdade ao longo da barra Fig. (3.3).

O mancal de rolamento de $\mathrm{N}^{\circ} .6203$ usado no carro possui especificações acima das necessárias, com capacidade de carga estática de $4,75 \mathrm{kN}$, onde o peso do dispositivo do dispositivo é de cerca de 515 N. Foi selecionado portanto, em função de possuir um dos menores valores do mercado.

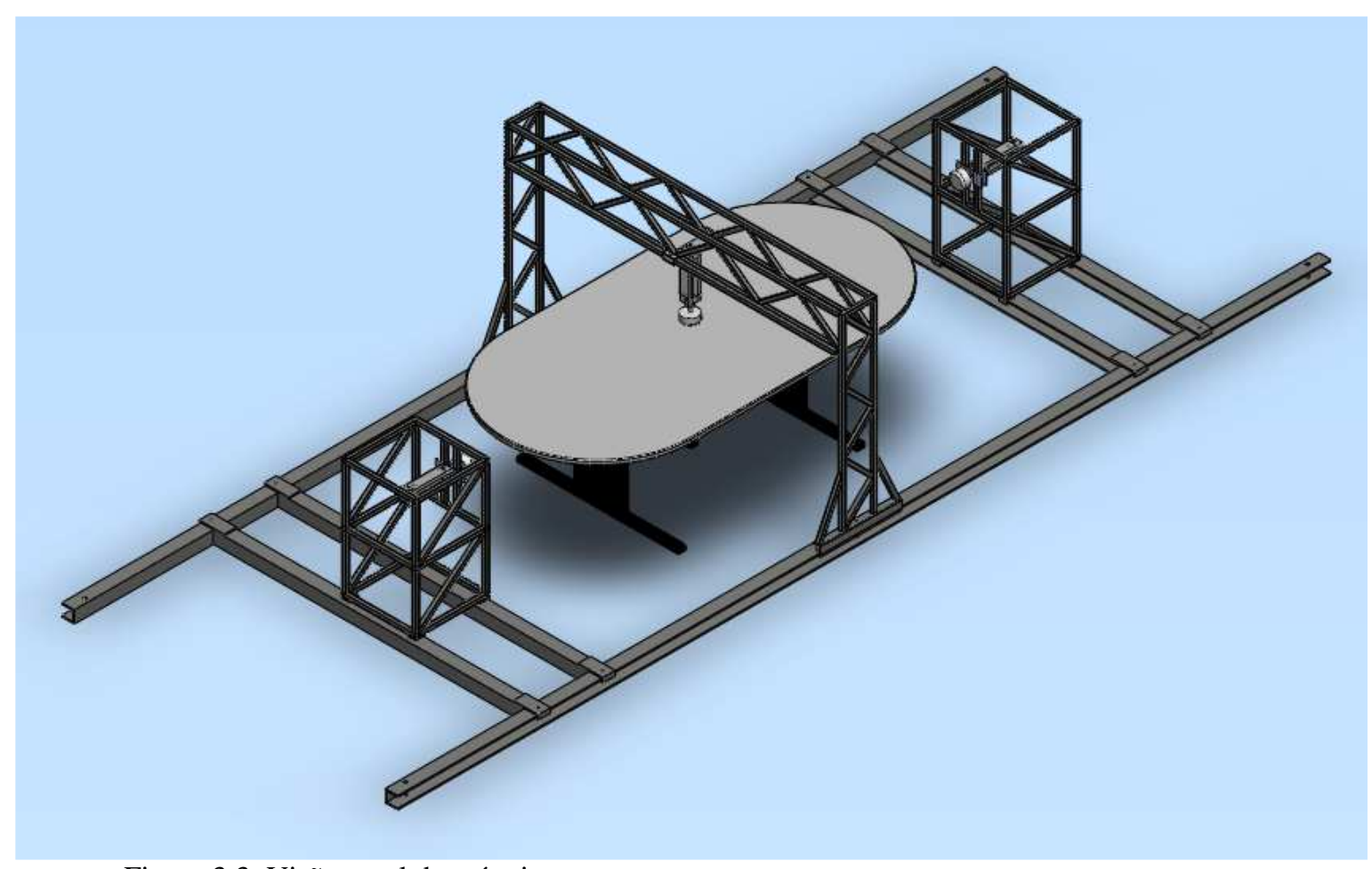

Figura 3.3. Visão geral da máquina.

Fazendo um exame crítico a partir de um modelo virtual produzido em CAD (SolidWorks ${ }^{\circledR}$ ), é obtido um modelo que ira servir de base para as análises de estrutura e interatividade entre os componentes.

Os próximos passos são realizar os cálculos, baseada na análise dos elementos envolvidos, e iniciar o projeto em si, assistido pelas soluções propostas para problemas aqui levantados. 


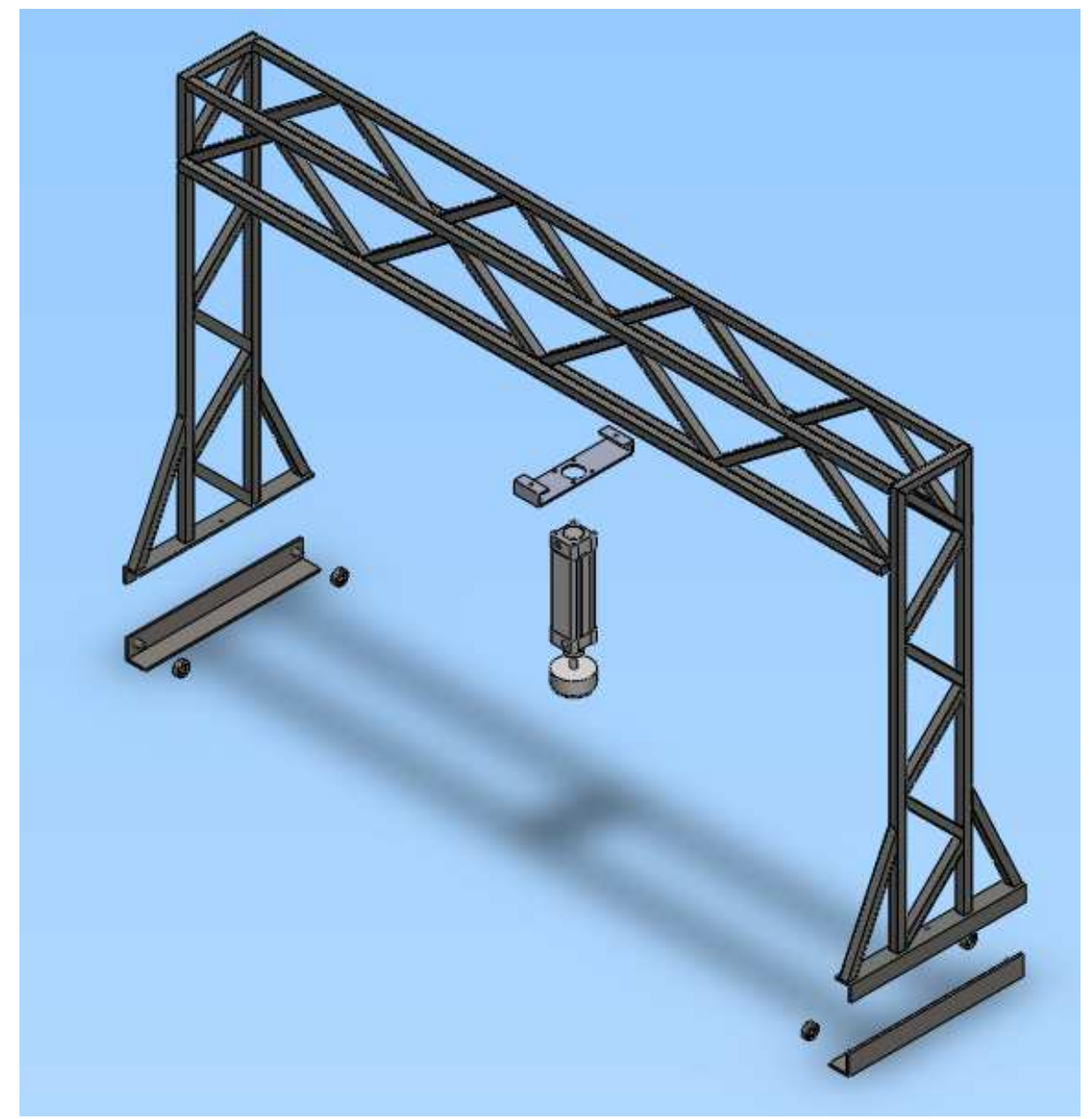

Figura 3.4. Vista explodida do dispositivo de ensaio vertical.

\subsubsection{Movimentação e Fixação da Máquina}

O posicionamento dos elementos da máquina deve prezar pela mobilidade, conferindo agilidade e menor esforço possível na tarefa. Os carros de ensaios horizontais têm peso razoável, poderão ser arrastados com certa facilidade ao longo dos trilhos laterais, a levar em consideração a massa das barras com perfil em U. A imobilização do carro será feita por um parafuso no topo das extremidades das barras do carro, como visto na Figura (3.5).

Esse tipo de imobilização é seguro, e tendo em conta a nova forma de apoio dos carros, não terá esforços além da baixa pré-carga necessária para produzir uma força de atrito superior a da carga horizontal de $450 \mathrm{~N}$ dividida por quatro. A força de atrito que cada parafuso terá que fornecer será de $112.5 \mathrm{~N}$, com um coeficiente de atrito de Aço-Aço de 0.74, o parafuso selecionado foi o tipo M10 e possui limite a fadiga de $162 \mathrm{MPa}$, valor tabelado de acordo com a equação de Marin para parafusos ISO M5-M36 (Shigley).

$F=N \mu$

$N=\frac{F}{\mu}=\frac{112,5}{0,74}=152,03 \mathrm{~N}$ 
Com esta força, a tensão no parafuso é de $6.08 \mathrm{MPa}$, quatro por cento da tensão limite a fadiga.

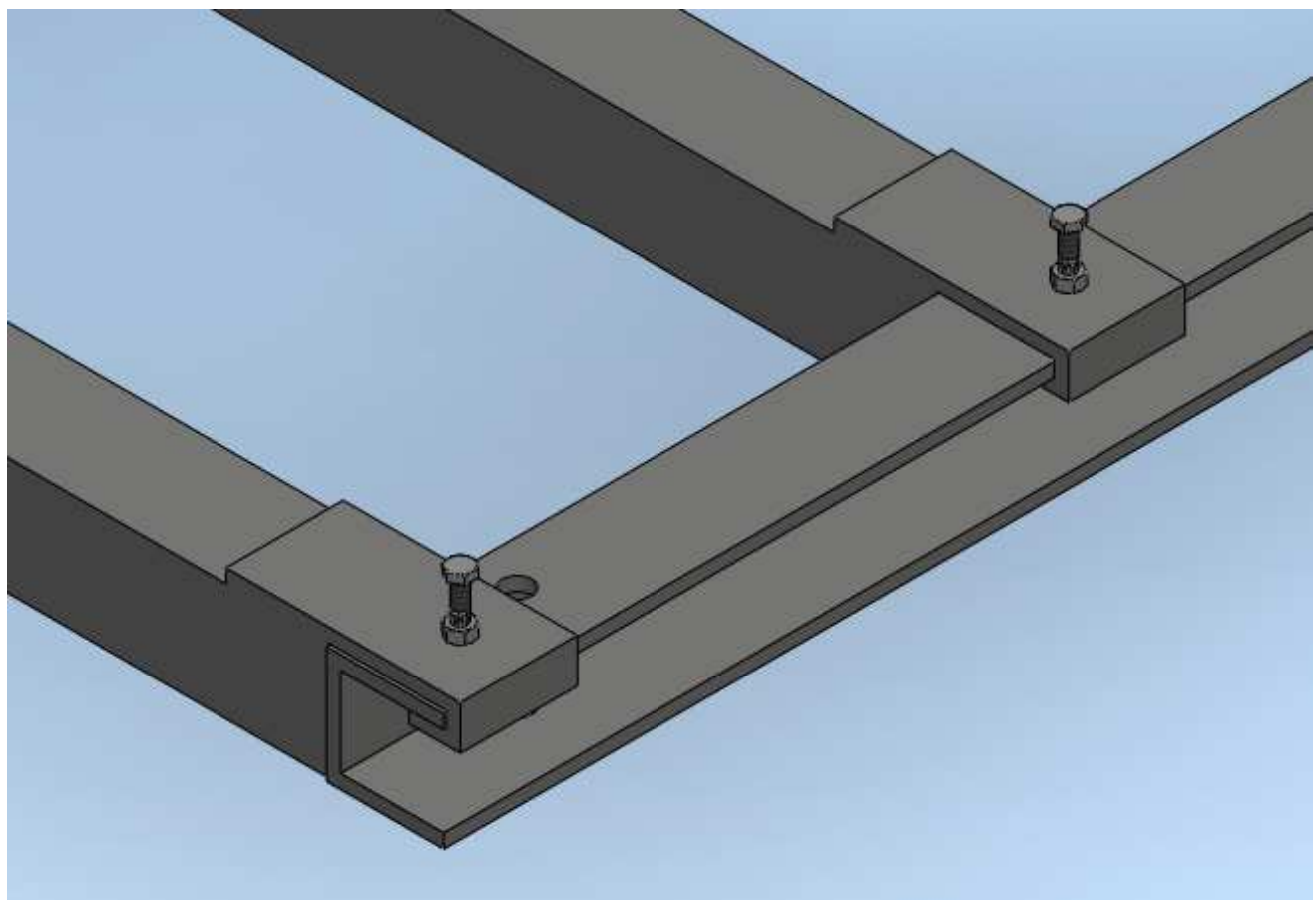

Figura 3.5. Detalhe da imobilização da barra do carro horizontal.

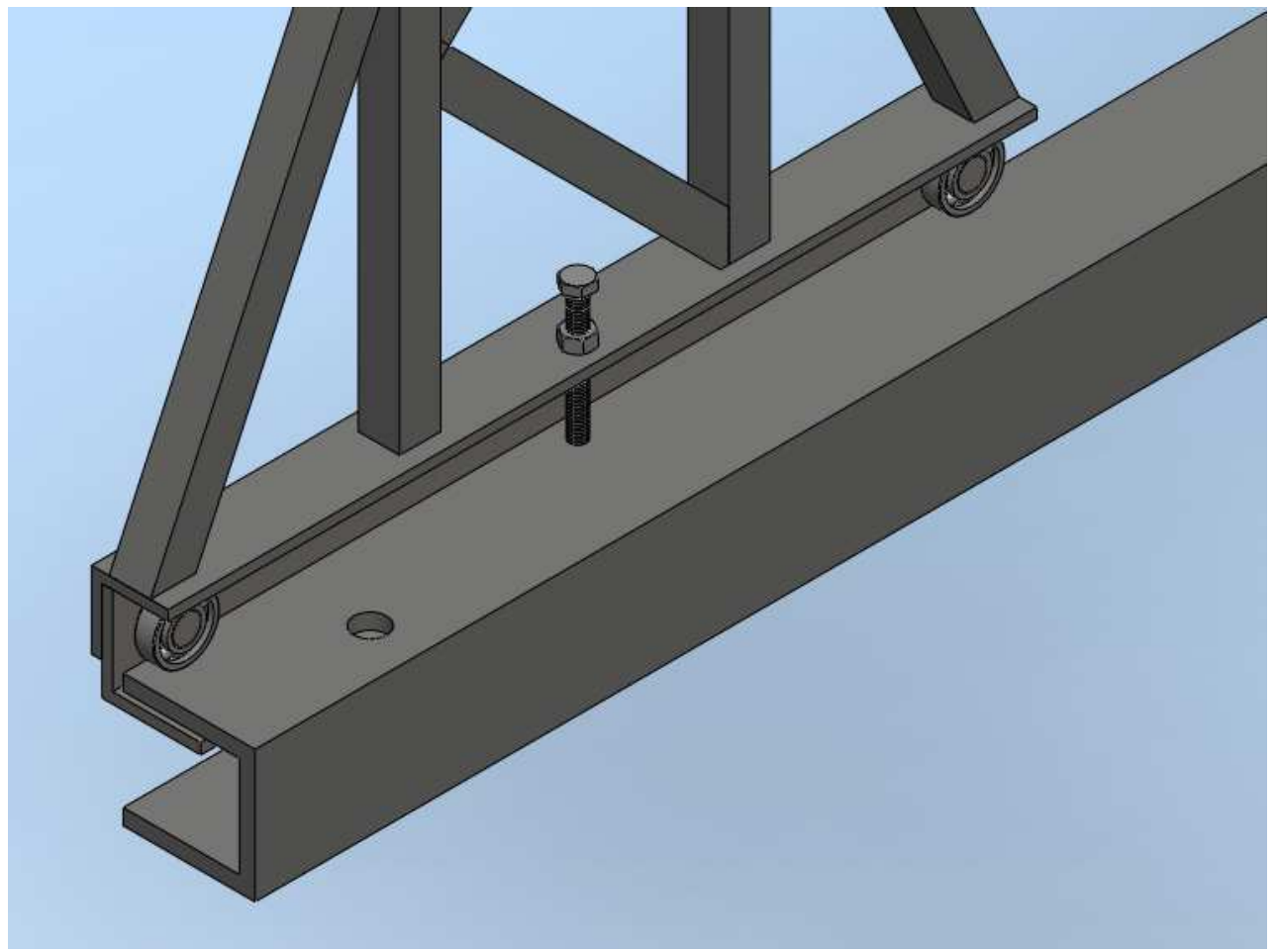

Figura 3.6. Detalhe de imobilização do carro vertical. 
O movimento do carro de ensaios verticais se da através do apoio sobre os trilhos laterais, também produzidos com o perfil em $\mathrm{U}$, através de rolamentos de esferas, com objetivo de facilitar ao máximo o posicionamento da almofada de testes sobre a mesa. A imobilização também se da por parafusos posicionados no topo da base do carro, de forma a pressionar a aba do perfil em L contra os trilhos, como visto na Figura (3.6). 


\section{DIMENSIONAMENTO DA MÁQUINA}

\subsection{ANÁLISE MATEMÁTICA}

A análise matemática se faz necessária em virtude das limitações do programa COSMOSXpress ${ }^{\circledR}$ na resolução de certos problemas, como no caso do cálculo de uma estrutura em treliça, e no estabelecimento dos esforços sofridos pela interação com outras peças, esforços estes usados posteriormente nas simulações.

\subsubsection{Cálculo dos Esforços nos Carregamentos de Ensaios Horizontais}

As forças envolvidas foram calculadas a partir do método do Diagrama de Corpo Livre, que determina os carregamentos em função da interação entre os componentes da máquina. Especificados os pontos de aplicação das forças e respectivas reações, o passo seguinte é a aplicação do somatório dos momentos e das forças em todas as direções e sentidos.

A Figura (4.1) mostra as forças e reações relevantes no carro, que por sua vez é responsável pela deflexão da barra de apoio do deste. Foi utilizada uma representação bidimensional em virtude da simetria do carregamento. Diante da dificuldade de se determinar a posição exata da aplicação das forças, arbitrou-se as extremidades do carro em função de serem os pontos onde as solicitações são críticas.

Com a análise do carregamento e determinado o Diagrama de Corpo Livre, encaminha-se para a determinação de R1, que é a força de reação que irá agir na barra de apoio. A determinação de R1 é feita aplicando-se as equações do equilíbrio:

$$
\begin{aligned}
& \sum F_{x}=0 \\
& \sum F_{y}=0 \\
& \sum M_{z}=0
\end{aligned}
$$

Do diagrama de corpo livre, temos que $\sum F_{x}=F 1$ e $\sum F_{y}=R 1$ portanto, pelo somatório de momentos temos:

$$
\sum M_{z}=0
$$




$$
\begin{aligned}
& F 1.0,8-R 1 \cdot 0,475=0 \\
& R 1=\frac{450 \cdot 0,8}{0,475} \\
& R 1 \cong 760 N
\end{aligned}
$$

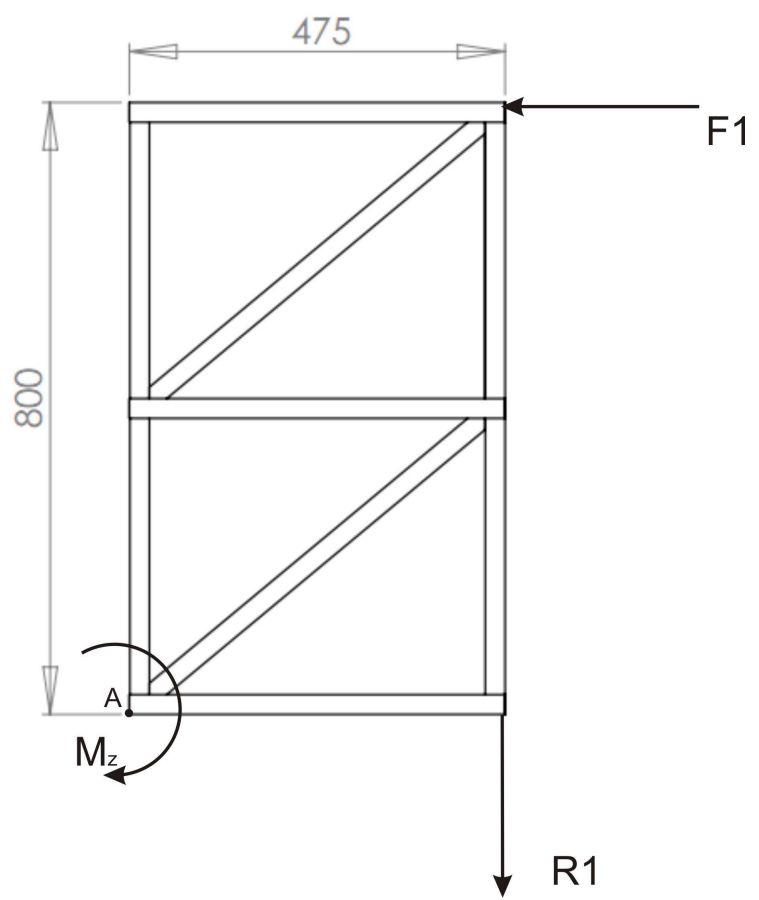

Figura 4.1. Diagrama de corpo livre do carro.

Com esses dados, obtém-se a força que age na barra de apoio do carro, utilizada no carregamento da simulação feita no COSMOSXpress ${ }^{\circledR}$.

\subsubsection{Cálculo dos Esforços nos Carregamentos de Ensaios Verticais}

Para realizar o dimensionamento da treliça do carro de ensaio vertical, foram necessários alguns cálculos preliminares, que possibilitaram a análise computacional.

Os cálculos dos esforços e das cargas axiais nas barras são realizados utilizando o Método das Seções ou Método de Ritter. Esse método é selecionado em função da possibilidade de se calcular os esforços em diferentes pontos da treliça, sem a necessidade do cálculo em todos os nós. Os seguintes passos determinam o método:

- Secciona-se a treliça em duas partes e em um ponto onde se tenha no máximo três incógnitas.

- Seleciona-se uma das partes para os cálculos.

- A partir deste ponto aplicam-se as equações do equilíbrio normalmente. Vale observar que qualquer nó pode ser escolhido como ponto de apoio para a solução. 


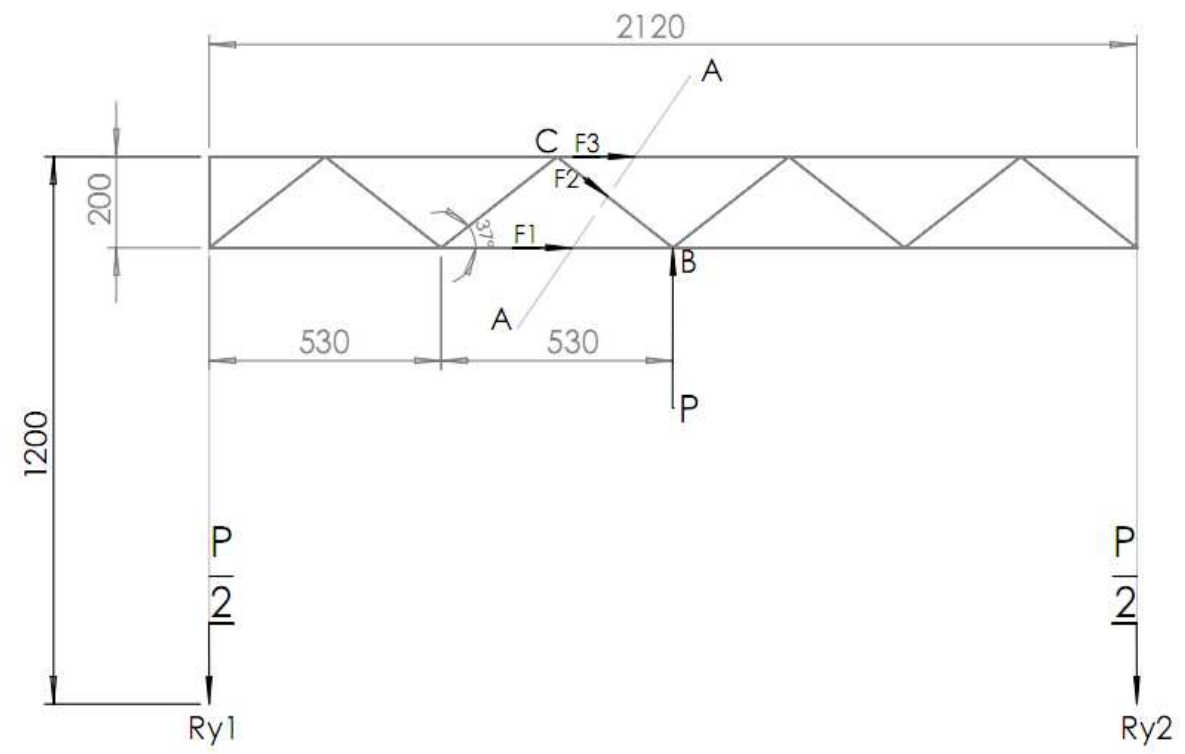

Figura 4.2. Carro de ensaio vertical. Esquema da estrutura treliçada.

A figura (4.2) mostra o esquema da estrutura a ser analisada. Como o carregamento $\mathrm{P}$ esta posicionado exatamente no centro, de forma que se tenha o maior momento fletor, a seção AA é conveniente.

A solução da treliça tem seu início com a determinação das reações de apoio. Neste caso em especial, o carregamento e a estrutura são simétricos, então se conclui que $R y 1=R y 2=P / 2$. As equações (2), (3) e (4) do equilíbrio podem ser aplicadas, considerando o ponto B como ponto de giração. Então:

$\sum M_{B}=0$

$-F 3.0,2+\frac{P}{2} \cdot 1,06=0$

$F 3=2,65 P$

$\sum F_{y}=0$

$-F 2 \cdot \sin 37^{\circ}-\frac{P}{2}=0$

$F 2=0,83 P$

$\sum F_{x}=0$ 
$F 2 \cdot \cos 37^{\circ}+F 1=0$

$F 1=-0,66 P$

Foi arbitrado que todas as barras seriam tracionadas, conferindo um valor positivo para sua direção, $F 2$ e $F 3$ com valor positivo indicam que sofrem tração de fato, seguindo essa linha, o valor negativo encontrado para a força $F 1$ indica que a barra sofre compressão. Estes valores foram utilizados na simulação feita com o auxílio do pacote COSMOSXpress ${ }^{\circledR}$ e estão disponíveis no Apêndice.

Para a treliça lateral, considerando que a força exercida nas laterais é de $P / 2$, mesmo que fosse somente uma barra sustentando a estrutura, a carga ficaria abaixo das encontradas na viga treliçada e utilizada nas simulações

Estes resultados são também utilizados para o cálculo de flambagem, falha catastrófica, que pode ocorrer em colunas sob compressão, mesmo que essas estejam com tensões distantes da tensão de escoamento. As equações (4) e (5) exprimem a carga crítica de colapso $P_{c r}$.

As dimensões características de cada coluna resultam em um coeficiente, chamado de coeficiente de esbeltez $(l / k)$, onde $k$ é o raio de giração e $l$ o comprimento da coluna. Para colunas com extremidades arredondadas utiliza-se a equação conhecida como fórmula da coluna de Euler Eq. (4), em casos onde o coeficiente de esbeltez não atende a fórmula de Euler, utiliza-se a equação conhecida como fórmula parabólica ou de J. B. Johnson, Eq. (5). Ambas as equações estão na sua forma geral.

$$
\begin{aligned}
& P_{c r}=\frac{\pi^{2} \cdot E \cdot I}{l^{2}} \\
& \frac{P_{c r}}{A}=a-b \cdot\left(\frac{l}{k}\right)^{2}
\end{aligned}
$$

Onde a e b são as constantes que são avaliadas ajustando-as a uma curva parabólica de Euler onde $a=S_{y}$ e $b$ é dado pela fórmula:

$$
b=\left(\frac{S_{y}}{2 . \pi}\right)^{2} \cdot \frac{1}{C . E}
$$

A Figura (4.3) mostra a curva que relaciona o coeficiente de esbeltez com a carga unitária, mostrando o limite $(l / k)_{1}$, que determina qual das equações Equação (4) ou (5) se devem usar. 


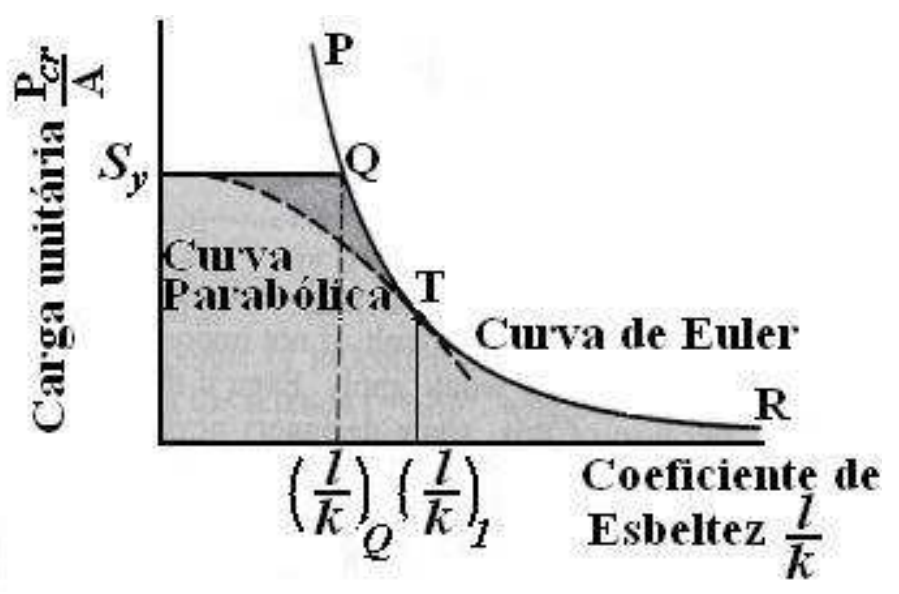

Figura 4.3. Curva de Euler (Shigley).

Sendo que $(l / k)$ é dado por:

$$
\left(\frac{l}{k}\right)_{1}=\left(\frac{2 \cdot \pi C \cdot E}{S_{y}}\right)^{1 / 2}
$$

Onde:

$$
k=\sqrt{\frac{I}{A}}
$$

Para o caso da coluna da treliça em particular foi selecionado um tubo de perfil quadrado com 25 mm de largura de seção com 1,5 mm de espessura de parede. Os cálculos são realizados considerando os seguintes dados:

$l=530 \mathrm{~mm}$

$I=\frac{h_{1}^{4}-h_{2}^{4}}{12}$

$A_{s}=h_{1}{ }^{2}-h_{2}{ }^{2}$

$P=660 N$

Onde $h_{1}=25 \mathrm{~mm}$ e $h_{2}=22 \mathrm{~mm}$.

Agora utiliza-se a Equação (8) para obter o $k$ e poder calcular $(l / k)_{1}$ e $(l / k)$ : 
$k=\sqrt{\frac{I}{A}}=\frac{h_{1}^{2}+h_{2}^{2}}{12}=92,4$

$\frac{l}{k}=\frac{530}{92,4}=5,73$

$\left(\frac{l}{k}\right)_{1}=\left(\frac{2 \cdot \pi^{2} C \cdot E}{S_{y}}\right)^{1 / 2}=\left(\frac{2 \cdot \pi^{2} \cdot 1 \cdot 207}{350}\right)^{1 / 2}\left(\frac{10^{9}}{10^{6}}\right)^{1 / 2}=108,05$

Como $\frac{l}{k} \leq\left(\frac{l}{k}\right)_{1}$, então trata-se de uma coluna de J. B. Johnson, usa-se então a Equação (5) substituindo as constantes $a$ e $b$ de acordo com as condições de contorno retiradas da Figura (4.3) e de $(l / k)_{1}:$

$\frac{P_{c r}}{A}=S_{y}-\left(\frac{S_{y}}{2 . \pi} \cdot \frac{l}{k}\right)^{2} \cdot \frac{1}{C . E}$

$\frac{P_{c r}}{A}=350.10^{6}-\left(\frac{350.10^{6}}{2 . \pi} .5,74\right)^{2} \cdot \frac{1}{1.207 .10^{9}}=349,5.10^{6}$

$P_{c r}=49,28 \mathrm{kN}$

Observando a elevada carga crítica e tensão de flambagem, fica claro que se trata de uma coluna curta, onde as forças que promovem a flambagem produzem tensões próximas as de escoamento.

Para calcular os efeitos dos carregamentos no carro vertical em contato com o trilho, é necessário que seja feita uma análise através do diagrama de corpo livre, a fim de averiguar as forças e momentos envolvidos, Fig. (4.4).
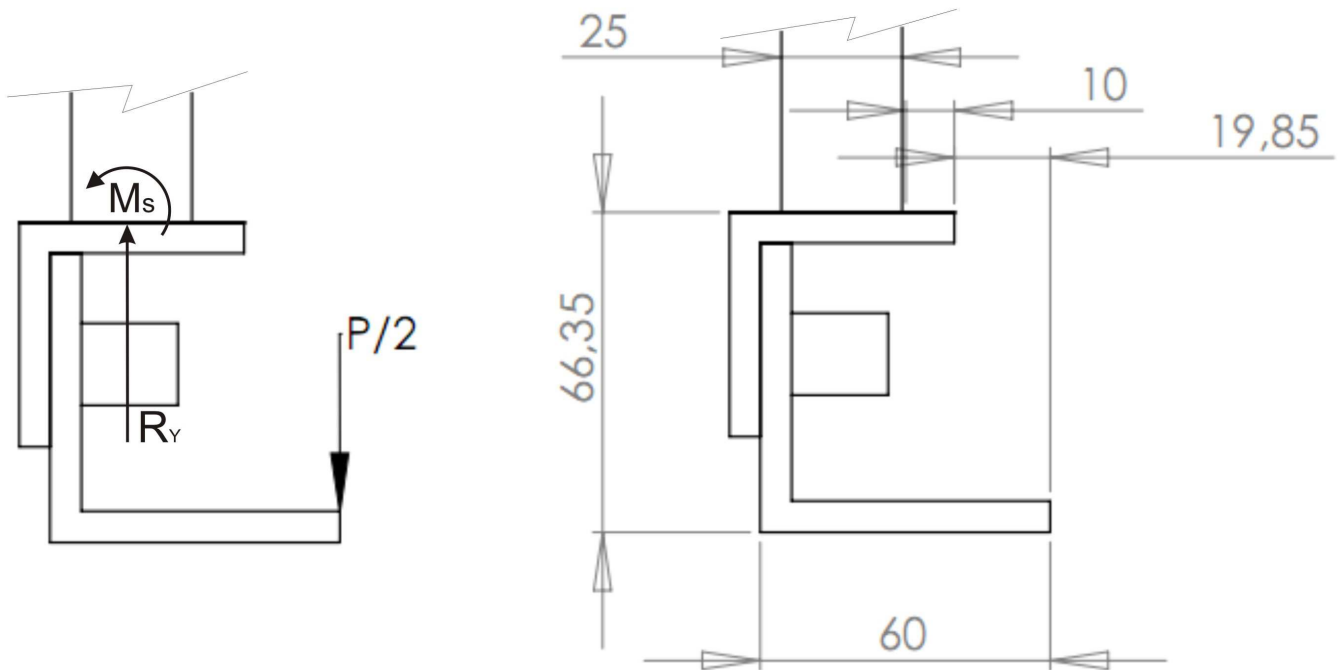

Figura 4.4. Carro em contato com o trilho. 
As equações (2), (3) e (4) do equilíbrio podem ser aplicadas, fornecendo as reações na treliça lateral, que serviram para determinar as tensões nos filetes de solda.

$$
\begin{aligned}
& \sum F_{Y}=0 \\
& \frac{P}{2}+R_{Y}=0 \\
& R_{Y}=-\frac{P}{2}=500 \mathrm{~N} \\
& \sum M_{z}=0 \\
& M_{S}-0,042 \cdot 500=0 \\
& M_{S}=21,175 \mathrm{~N} \cdot m \\
& \sum F_{x}=0
\end{aligned}
$$

No cálculo das tensões normais e cisalhantes é necessário utilizar o momento de inércia baseado na penetração da solda no material, dado pela equação (Shigley):

$$
I=0,707 h \frac{b d^{2}}{2}
$$

Substituindo na equação de tensão normal,

$$
\tau=\frac{M \cdot c}{I}=\frac{M(d / 2)}{0,707 b d^{2} h / 2}=\frac{1,414 M}{b d h}
$$

Onde $h$ é a largura do cordão de solda, $d$ é a distância entre soldas e $b$ é o comprimento do filete de solda, que no caso tem o mesmo valor de $d$ pois o tubo da estrutura possui perfil quadrado de $25 \mathrm{~mm}$ largura com $1.5 \mathrm{~mm}$ de espessura. A tensão cisalhante é dada por:

$$
\tau=\frac{V}{A}
$$

As variáveis possuem os seguintes valores:

$h=0.0015 m$

$d=0.025 m$

$b=0.025 m$

A tensão nominal então é dada por:

$$
\begin{aligned}
\tau^{\prime} & =\frac{1,414 M_{S}}{b d h} \\
\tau^{\prime} & =\frac{1,414 \cdot 21,175}{0,025 \cdot 0,025 \cdot 0,0015} \\
\tau^{\prime} & =31,9 M P a
\end{aligned}
$$


A tensão cisalhante leva em conta a área total de penetração da solda, $A=1,414 \cdot b \cdot h$ e tem o seguinte valor:

$A=1,414 \cdot b \cdot h=1,414 \cdot 0,025 \cdot 0,0015=5,3 \cdot 10^{-5} \mathrm{~m}^{2}$

A tensão cisalhante então:

$$
\begin{aligned}
\tau^{\prime \prime} & =\frac{V}{A} \\
\tau^{\prime \prime} & =\frac{500}{5,3 \cdot 10^{-5}}=9,26 \mathrm{MPa}
\end{aligned}
$$

A tensão cisalhante total é dada pelo somatório das duas tensões:

$$
\begin{aligned}
& \tau=\tau^{\prime}+\tau^{\prime \prime} \\
& \tau=31,9+9,26=41,16 \mathrm{MPa}
\end{aligned}
$$

Este valor considera a estrutura do carro soldada a apenas uma barra da treliça lateral, entretanto, existem quatro barras soldadas e que dividem igualmente os esforços. Com isso, a tensão encontrada anteriormente fica reduzida a um quarto.

$$
\tau_{\text {total }}=\frac{41,16}{4}=10,29 \mathrm{MPa}
$$

\subsubsection{Análise de Fadiga}

O critério de Marin é utilizado para a análise de fadiga, onde fatores atribuem grandeza a condições específicas dos elementos da máquina, tais como fator de condição de superfície, temperatura, carregamento e uma série de outros. A equação de Marin é escrita como:

$$
S_{e}=k_{a} k_{b} k_{c} k_{d} k_{e} k_{f} S_{e}^{\prime}
$$

Os fatores são dados por:

$k_{a}=a S_{u t}^{b}=272(427)^{-0.995}=0,661$

$d_{e}=0,808 \sqrt{h b}=0,808 \sqrt{25 \cdot 25}=20,2$

$k_{b}=\left(\frac{d_{e}}{0,3}\right)^{-0,1133}=\left(\frac{20,2}{0,3}\right)^{-0,1133}=0,62$

$k_{c}=0,85$

$k_{d}=1$

$k_{e}=0,753$

$k_{f}=2$

Todas as variáveis foram tiradas do livro Projeto de Engenharia Mecânica (Shigley). 
O cálculo de $S_{e}^{\prime}$ é realizado considerando que $S_{u t} \leq 1490 \mathrm{MPa}$ (Shigley). Com isso $S_{e}^{\prime}$ é calculado da seguinte forma:

$S_{e}^{\prime}=0,504 \cdot S_{u t}$

Para a solda em questão a resistência à tração é de $427 \mathrm{MPa}$.

$S_{e}^{\prime}=0,504 \cdot 427=215 \mathrm{MPa}$

$S_{e}=0,661 \cdot 0,62 \cdot 0,85 \cdot 1 \cdot 0,753 \cdot 2 \cdot 215=112,8 \mathrm{MPa}$

O limite de tensão $S_{e}$ comparado a maior tensão cisalhante encontrada:

$n=\frac{S_{e}}{\tau_{\text {total }}}=\frac{112,8}{10,29}=10,96$

Com um fator de projeto igual 2 o resultado final para o fator de segurança é:

$n=\frac{S_{e}}{\tau_{\text {total }}}=\frac{56,4}{10,29}=5,48$

\subsection{ANÁLISE COMPUTACIONAL}

\subsubsection{Análise da Máquina Existente}

Para o dimensionamento e posterior definição da maioria dos componentes da máquina de ensaio de mesas, utilizou-se como ferramenta o programa SolidWorks ${ }^{\circledR}$, bem como do pacote COSMOSXpress $^{\circledR}$ anexo ao programa, produzindo-se modelos virtuais desses componentes e realizando simulações, de acordo com os esforços a que serão submetidos.

Obtidas as reações recorrentes do carregamento, permitiu-se a simulação dos componentes existentes e em uso na máquina do Labmov, a fim de aferir as tensões e deformações correntes. Os resultados estão explicitados nas Figuras (4.4) e (4.5) e relacionados na Tabela (6) de resultados.

Vale ressaltar que as deformações encontradas não condizem com a deformação total da máquina, que deve levar em consideração um somatório das deformações de cada componente. Para determinar a deformação total, é necessário neste caso, realizar uma medição manual, através do uso de um relógio comparador. 


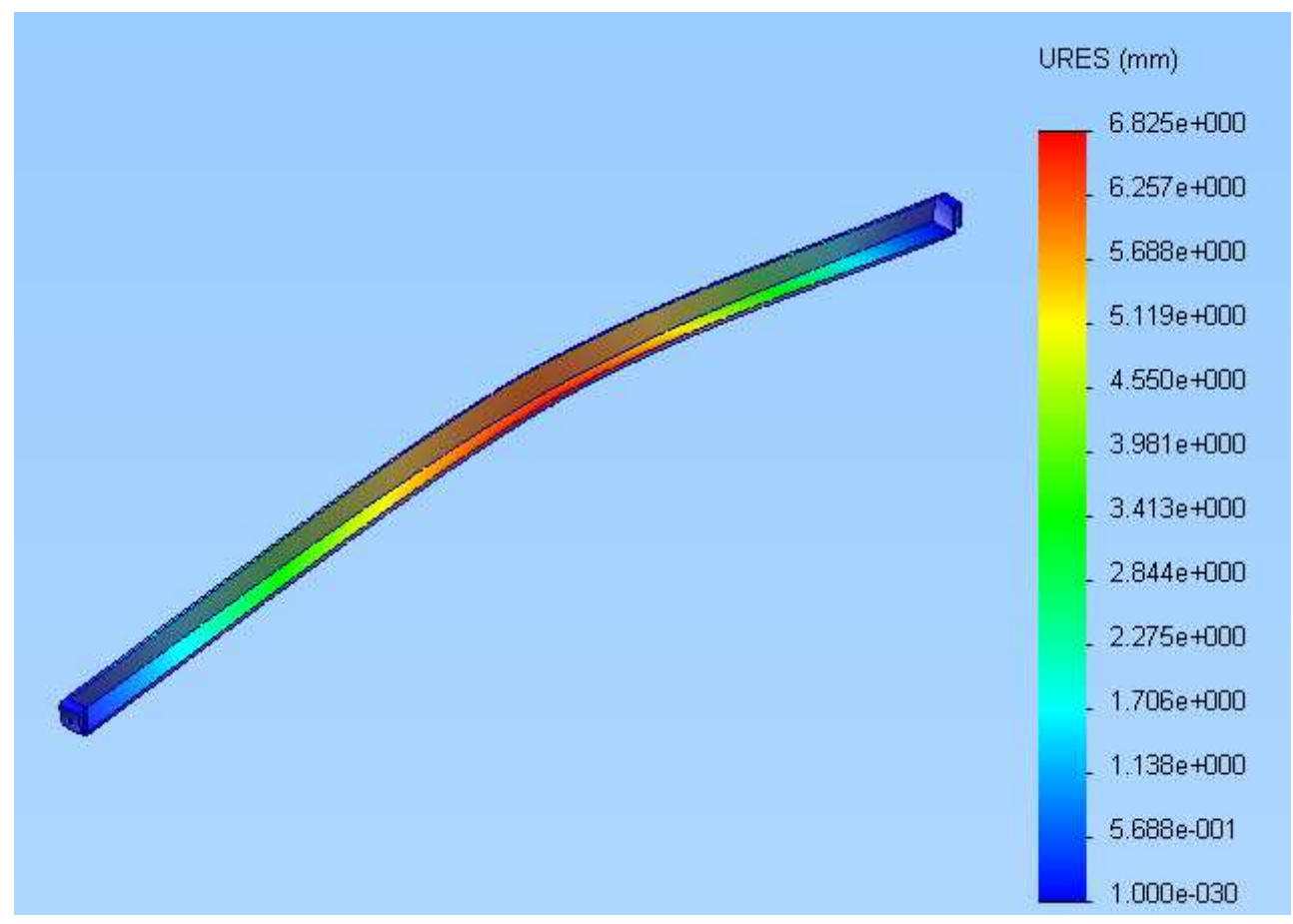

Figura 4.4. Barra de apoio do carro sob carga de 760 N. A escala indica a deformação.

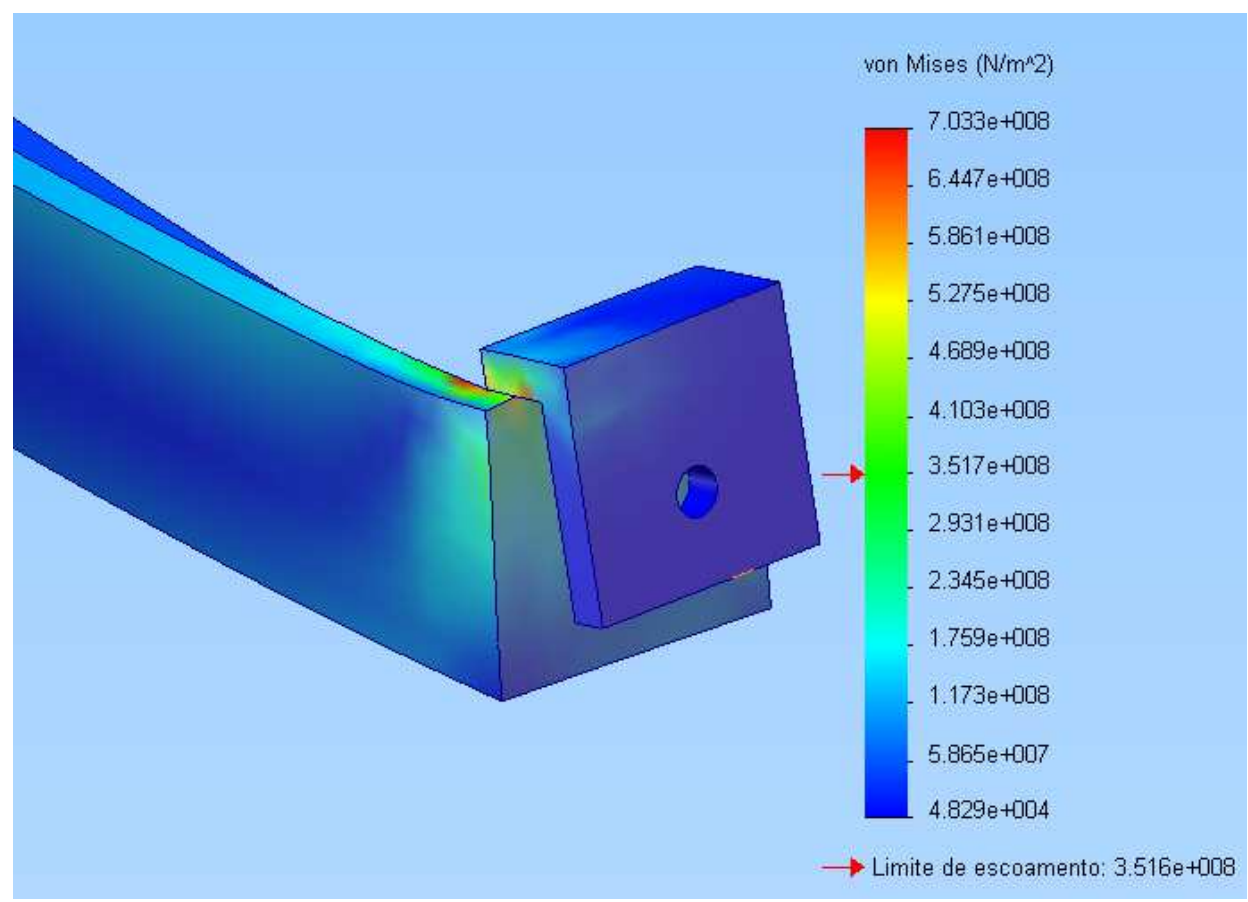

Figura 4.5. Barra de apoio do carro. A escala cromática à direita indica as tensões.

Diante destes dados, percebe-se a necessidade da substituição da peça por uma mais rígida e resistente, pois como é percebido na Figura (4.5), o fator de segurança em alguns pontos foi da ordem de 0.5, denunciando a iminente fratura, observada na rotina de ensaios do LabMov. Esta substituição visa eliminar os problemas com as deformações e as tensões nos pontos críticos. 
Outro ponto crítico que veio a ser resolvido com a substituição da barra de apoio é o de fixação. É observado na Figura (4.5) em detalhe que a peça em questão é presa aos trilhos de forma similar a uma pinça, o que induz uma tendência a escapar com a carga. Para que isso não ocorra necessita-se de um aperto maior no parafuso, conferindo uma pré-carga elevada em uma região onde as tensões já são elevadas (Fig. 4.5).

\subsubsection{Análise da Proposta para a Parte de Ensaio Horizontal}

A partir deste ponto, foi avaliado e selecionado um novo perfil para a barra de apoio do carro de ensaio horizontal, conferindo às partes uma nova forma e rigidez.

Foi arbitrado o perfil em U para análises prévias, em virtude do maior momento de inércia de secção, o que sabidamente confere uma maior rigidez. Foi executada uma simulação no pacote COSMOSXpress $^{\circledR}$ utilizando os dados da barra de apoio com perfil em L, submetendo a peça aos mesmo esforços.

Algumas dimensões de perfil foram estudadas até chegar a um perfil ótimo, considerando-se a rigidez e disponibilidade no mercado ou possibilidade de fabricação. Neste caso, foi necessário encomendar as barras com este determinado perfil em uma empresa especializada em dobra de chapa, já que os perfis prontos encontrados possuem rigidez abaixo da especificada para o projeto.

A forma final determinada foi simulada e se mostra adequada aos propósitos do projeto. Temos na Figura (4.6) a nova barra de apoio em sua representação de deformação.

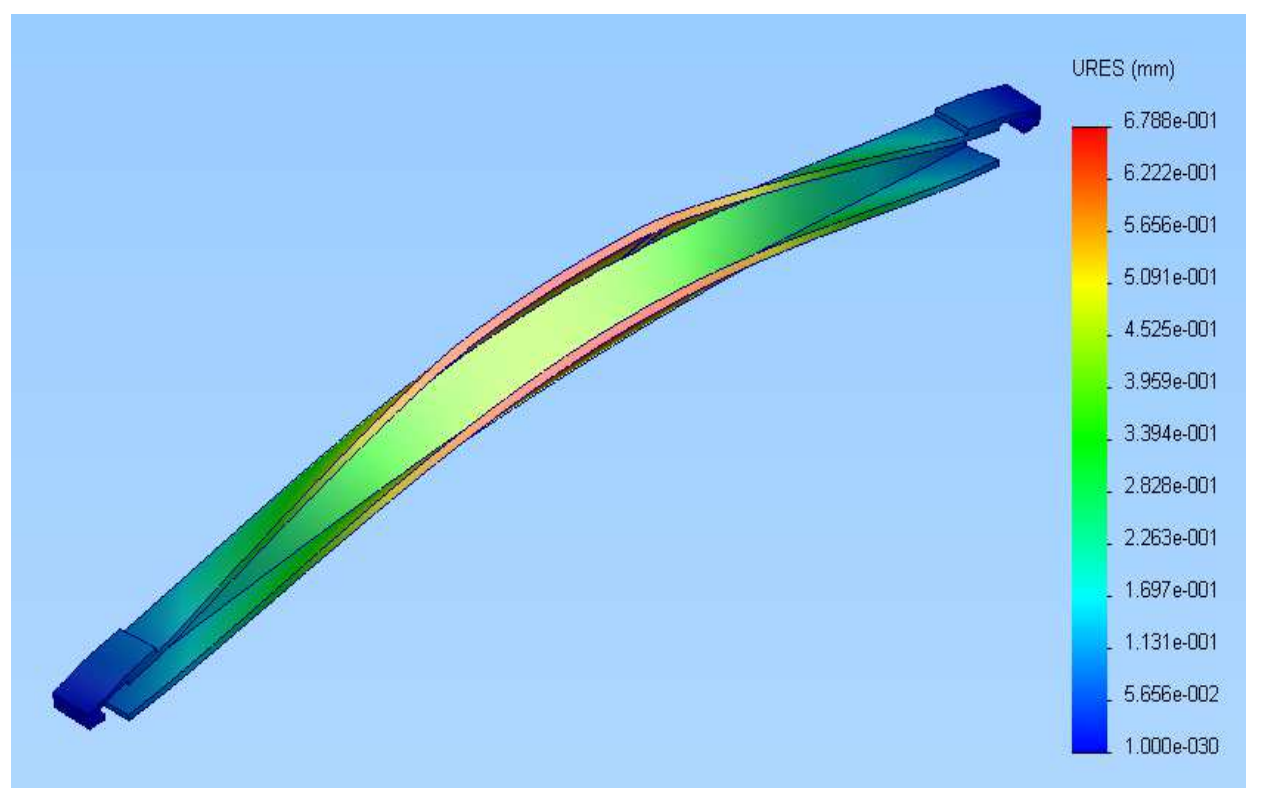

Figura 4.6. Perfil em U da barra de apoio. Simulação realizada no pacote COSMOSXpress ${ }^{\circledR}$. 
A tabela (2) mostra os resultados e permite um comparativo entre o dispositivo anterior e o proposto.

Tabela 6 - Comparativo entre as peças com os perfis antigo e atual.

\begin{tabular}{|c|c|c|c|}
\hline Partes & Tensão máxima & Deformação máxima & Fator de segurança mínimo \\
\hline Perfil em L & $703,3 \mathrm{MPa}$ & $6,82 \mathrm{~mm}$ & 0,5 \\
\hline Perfil em U & $29,9 \mathrm{MPa}$ & $6,78.10^{-1} \mathrm{~mm}$ & 11,74 \\
\hline
\end{tabular}

Como foi mencionado anteriormente, além da rigidez, outro ponto frágil da atual configuração é a forma de fixação do carro na barra de apoio, bem como da fixação da barra de apoio nas barras laterais, que tem forma de pinça.

O tipo de fixação no sentido de aplicação dos esforços, com o a configuração de abas, foi selecionado em detrimento de uma fixação em forma de pinça. A Figura (4.7) esclarece como ficou essa forma de fixação.

Notoriamente observa-se a maior facilidade e eficiência da fixação, a qual necessita apenas de uma pequena elevação da barra, fornecido com o acréscimo de um parafuso no topo, que promove o apoiamento da aba da barra de apoio na barra lateral.

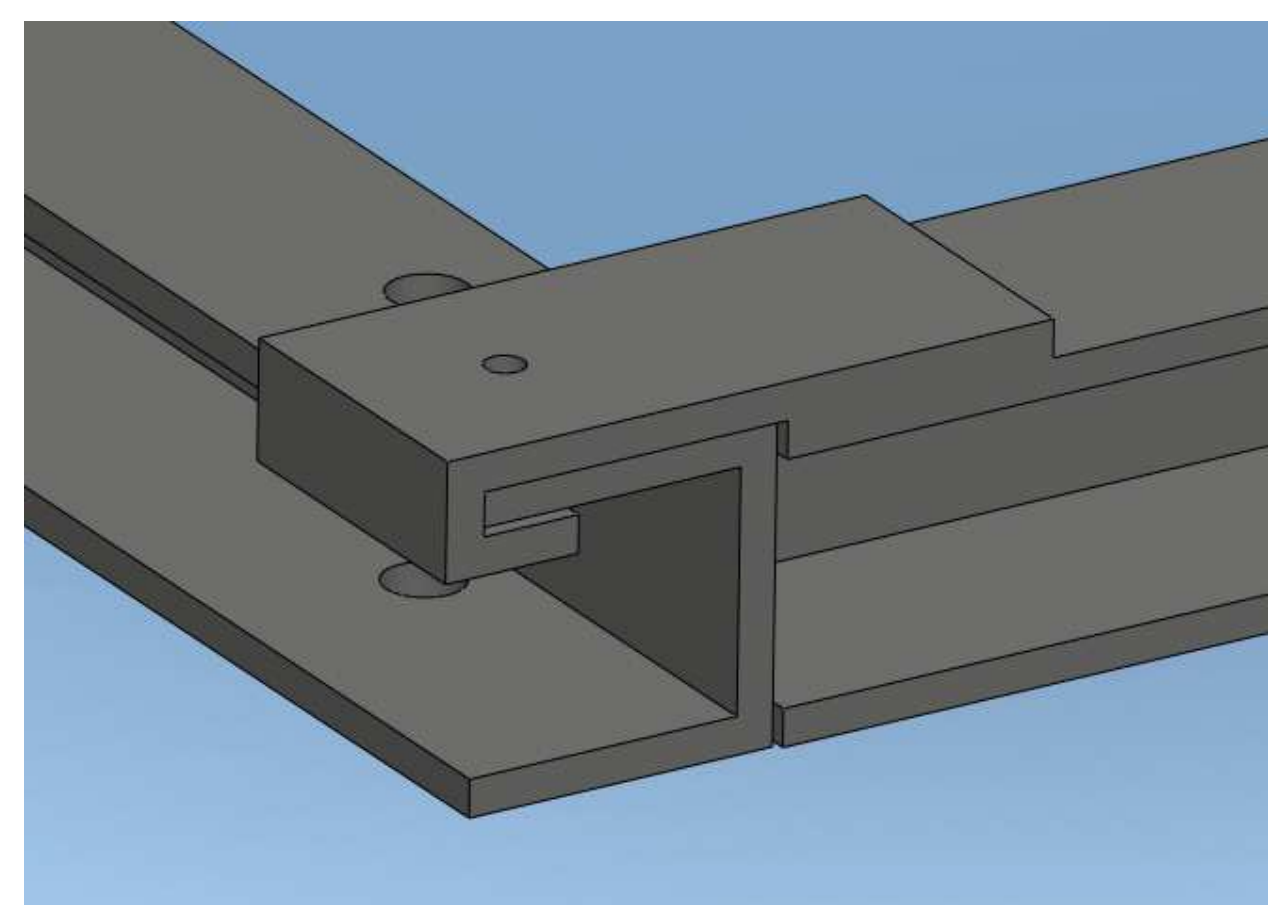

Figura 4.7. Detalhe da nova fixação. 
A reestruturação e dimensionamento da fração da máquina responsável pelo ensaio horizontal, foi concluída com o projeto do engate em forma de U (desenho () do apêndice), que soldado ao carro, irá fixa-lo a barra de apoio de forma que essa fixação seja perpendicular às forças resultantes do carregamento.

O dimensionamento foi realizado utilizando o pacote COSMOSXpress ${ }^{\circledR}$, e os resultados para tensão e deformação estão no Apêndice.

\subsubsection{Análise da Proposta Para a Parte de Ensaio Vertical}

As Figuras (3.2) e (3.3) demonstram como ficou a forma do dispositivo de aplicação de cargas verticais. A estrutura em forma de treliça, fabricada com barras de aço com perfil estrutural quadrado vazado de dimensões 25 x $25 \mathrm{~mm}$ e 1,5 mm de espessura, foi simulada utilizando os carregamentos calculados na seção 4.1.2 e forneceram os apresentados na tabela (7).

Tabela 7 - Dados obtidos para elemento da treliça.

\begin{tabular}{|c|c|c|c|}
\hline Partes & Tensão máxima & Deformação máxima & Fator de segurança mínimo \\
\hline Perfil quad. & $23,1 \mathrm{MPa}$ & $4,976.10^{-2} \mathrm{~mm}$ & 15,2 \\
\hline
\end{tabular}

Como uma treliça só possui cargas axiais, a simulação foi realizada utilizando uma das barras da treliça com comprimento de $530 \mathrm{~mm}$, que é o maior comprimento de uma barra.

Os dados obtidos, tabela (6), revelam o quanto as cargas são baixas em relação a resistência ao escoamento. A deformação máxima também é baixa e mesmo considerando toda a estrutura, com o somatório das deformações das quatro barras superiores da treliça, ainda assim a deformação total seria da ordem de centésimos de milímetros. 


\section{CONCLUSÕES}

Tendo como ponto de partida o aprimoramento da máquina existente e o projeto de um dispositivo para ensaios verticais, os resultados foram incisivos, com diminuição da rigidez da ordem de milímetros para ordem de décimos de milímetro.

Foi verificada a coerência entre os resultados obtidos através das simulações e os observados no cotidiano do laboratório, onde as deformações da máquina são visíveis, e as fraturas ocorrem com certa freqüência. A análise inicial, que contemplou os elementos existentes, impeliu o projeto de redimensionamento na direção mais crítica do dispositivo.

Os resultados alcançados em relação à correção de detalhes construtivos foram satisfatórios, os problemas que provocavam fraturas nas pinças de fixação das barras de apoio do carro de ensaios horizontais .A nova forma de fixação proposta e a mudança na geometria da secção transversal do perfil da estrutura se mostraram resistentes, quando realizadas simulações no pacote COSMOSXpress $^{\circledR}$, resultando em um aumento no fator de segurança de 0,5 para 11,7.

A treliça utilizada para o dispositivo de ensaios verticais também teve comportamento satisfatório, tendo as partes analisadas apresentando deformações na ordem de centésimos de milímetro, tensões máximas a dez por cento da tensão crítica, o que significa que as deformações não são visíveis a olho nu.

Apesar dos resultados satisfatórios, alguns pontos podem ser melhorados. $O$ pacote COSMOSWorks ${ }^{\circledR}$ que também pode ser usado através programa SolidWorks ${ }^{\circledR}$, é uma ferramenta mais poderosa do que o COSMOSXpress ${ }^{\circledR}$. O programa permite a simulação de flambagem, fadiga e outros fenômenos, conferindo cálculos mais rápidos em relação aos métodos usuais. A restrição ao seu uso nesse projeto se deve ao fato de necessitar de uma licença extra de preço elevado, o que inviabilizaria a aplicação, no sentido de se fazer a aquisição do pacote para esse projeto especificamente.

A máquina permite melhorias futuras, como uma regulagem de altura do carro de ensaios verticais que permita um melhor ajuste da altura, aumentando a variedade de ensaios realizados pela máquina. A fixação feita de forma pneumática também é uma melhoria a ser estudada, pois agiliza a preparação das mesas para o ensaio e consequentemente agiliza todo o processo. 


\section{REFERÊNCIAS BIBLIOGRÁFICAS}

NORTON, Robert L.. Projeto de máquinas: uma abordagem integrada. Tradução: João Batista de Aguiar, José Manuel de Aguiar. 2. ed. Porto Alegre: Bookman, 2004. 931p.

SHIGLEY, Joseph E.; MISCHKE, Charles L.; BUDYNAS, Richard G.. Projeto de engenharia mecânica. Tradução: João Batista de Aguiar, José Manuel de Aguiar. 7. ed. Porto Alegre: Bookman, 2005. 960 p.

BEER, F. P. \& JOHNSTON JR., E. R.. Mecânica Vetorial para Engenheiros: Estática, 5a Edição, Makron Books do Brasil Editora Ltda., 1994.

SILVA, Emílio Carlos Nelli. Apostila de pneumática. São Paulo, 2002. Disponível em: <http://www.poli.usp.br/d/pmr2480/pneumat2480.pdf>. Acesso em: 6 junho 2007.

PARKER TRAINING. Tecnologia pneumática industrial: Apostila M 1001 BR. Disponível em: <http://www.parker.com/br/download/training/pdf/m_1001.pdf>. Acesso em: 6 junho 2007.

ASSOCIAÇÃO BRASILEIRA DE NORMAS TÉCNICAS. NBR 13966: Móveis para escritório Mesas - Classificação, características físicas e dimensionais, requisitos e métodos de ensaio. Rio de Janeiro: ABNT, 2008. 


\section{APÊNDICE}

APÊNDICE A

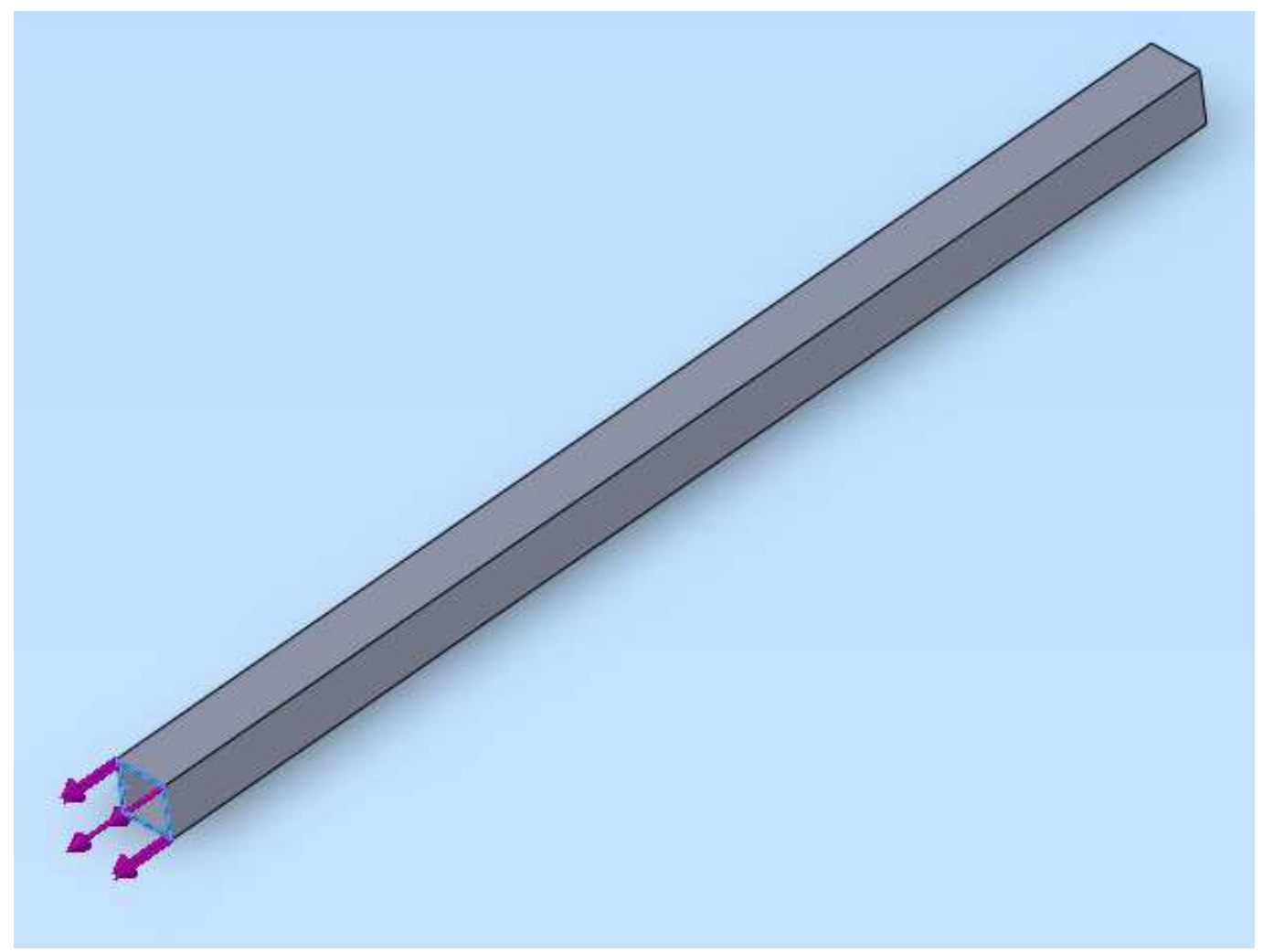

Figura 1A. Forma de aplicação de carga na barra da treliça.

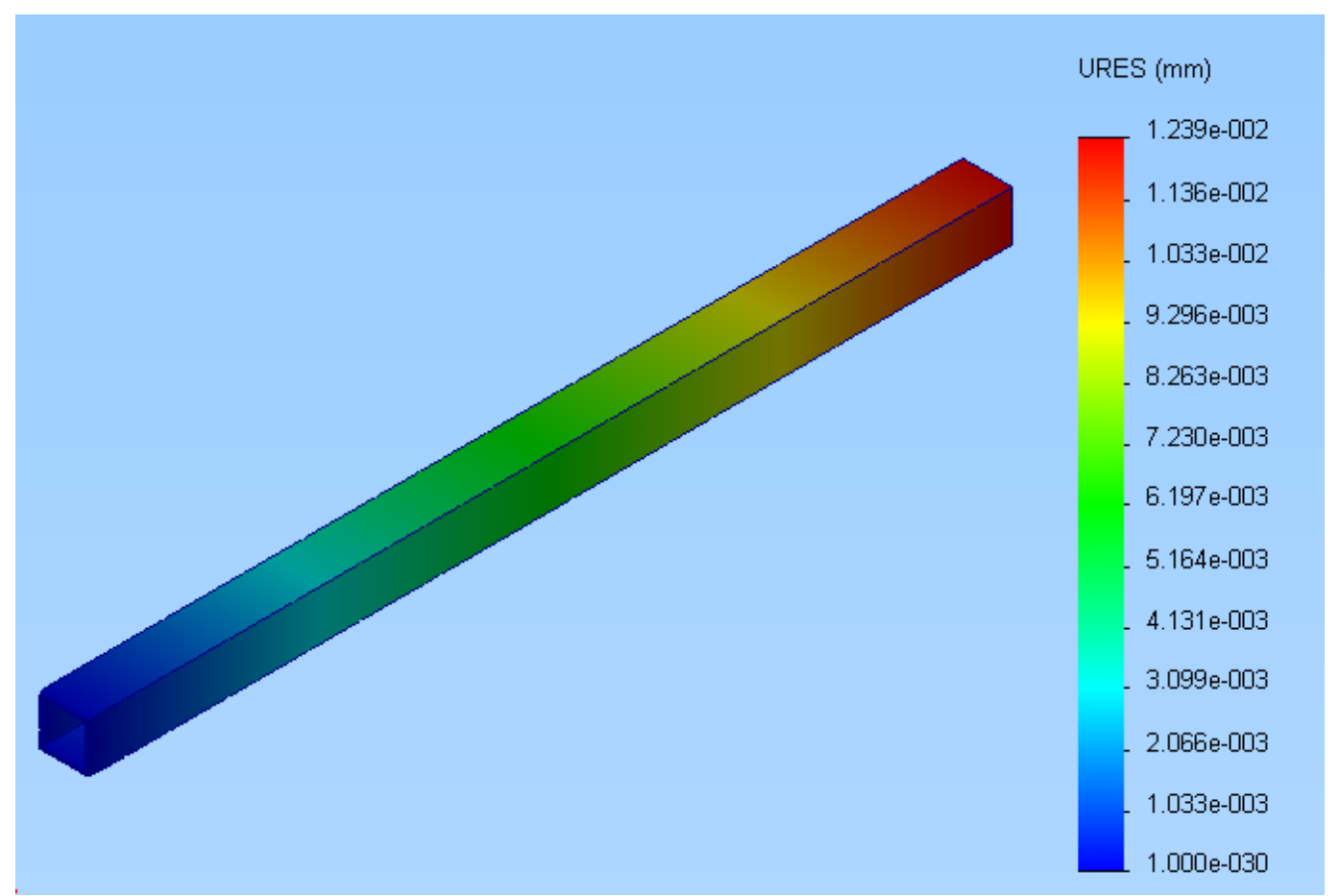

Figura 2A. Deformação da barra da treliça sob compressão. 


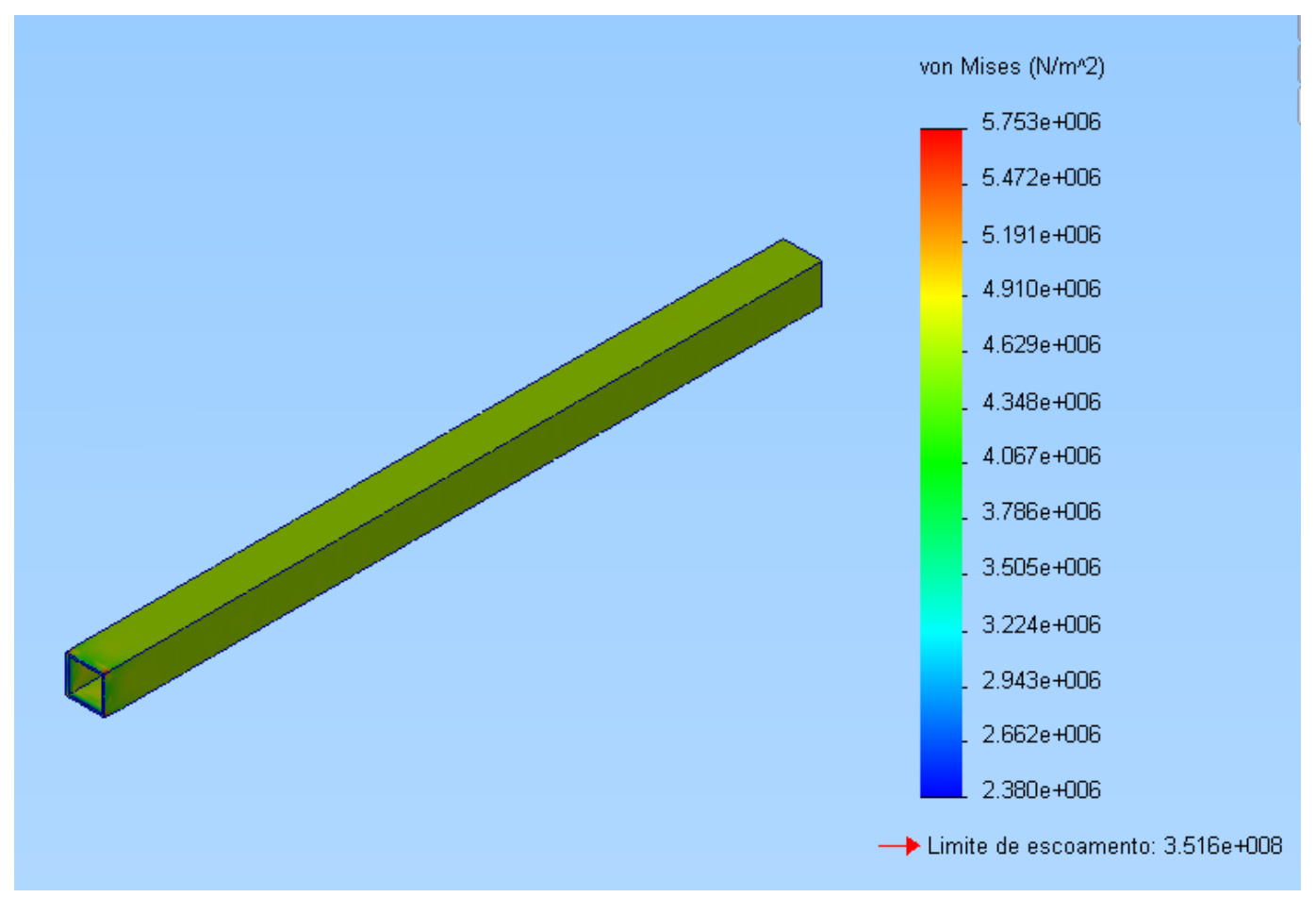

Figura 3A. Tensões na barra da treliça sob compressão.

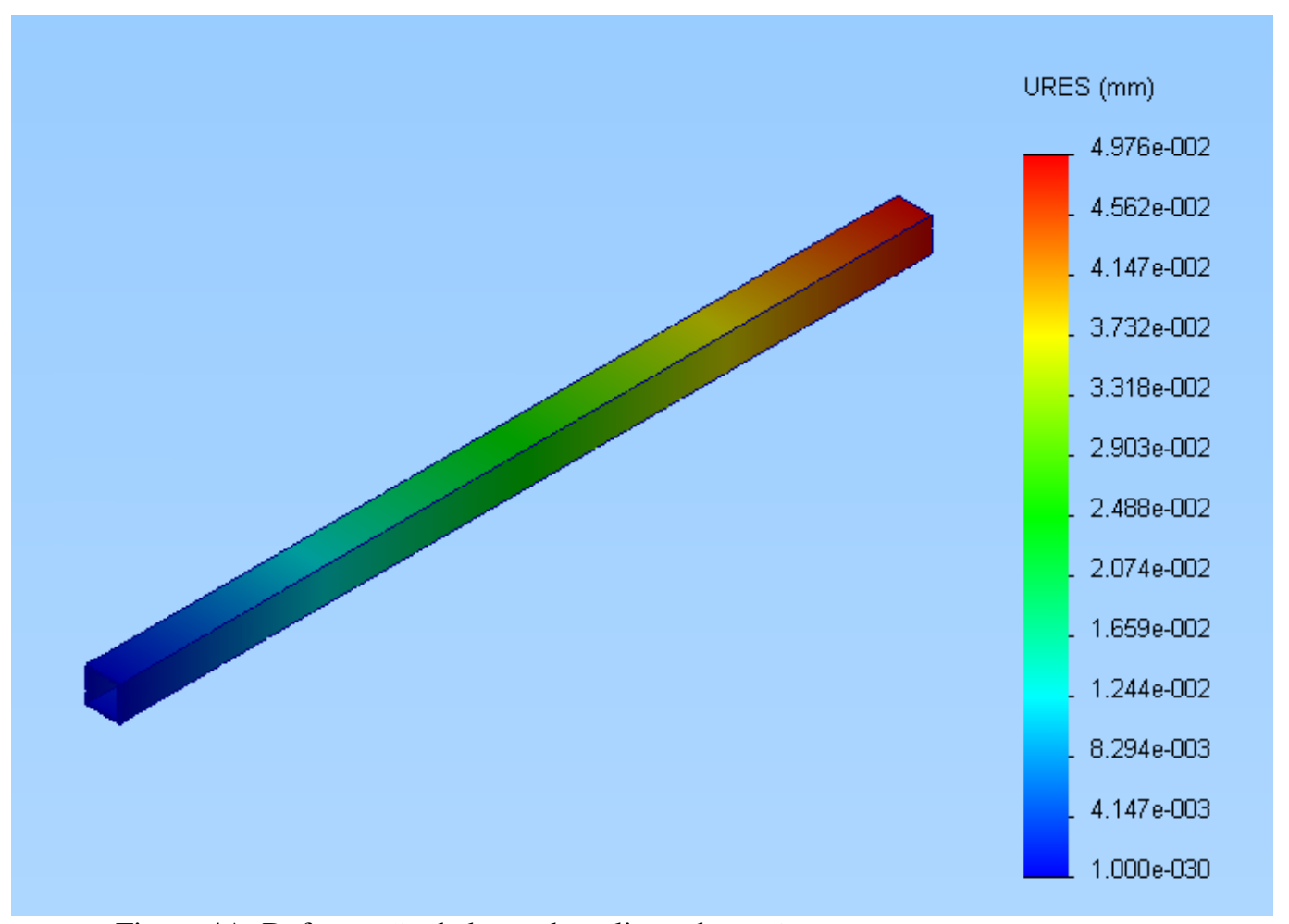

Figura 4A. Deformação da barra da treliça sob tração. 


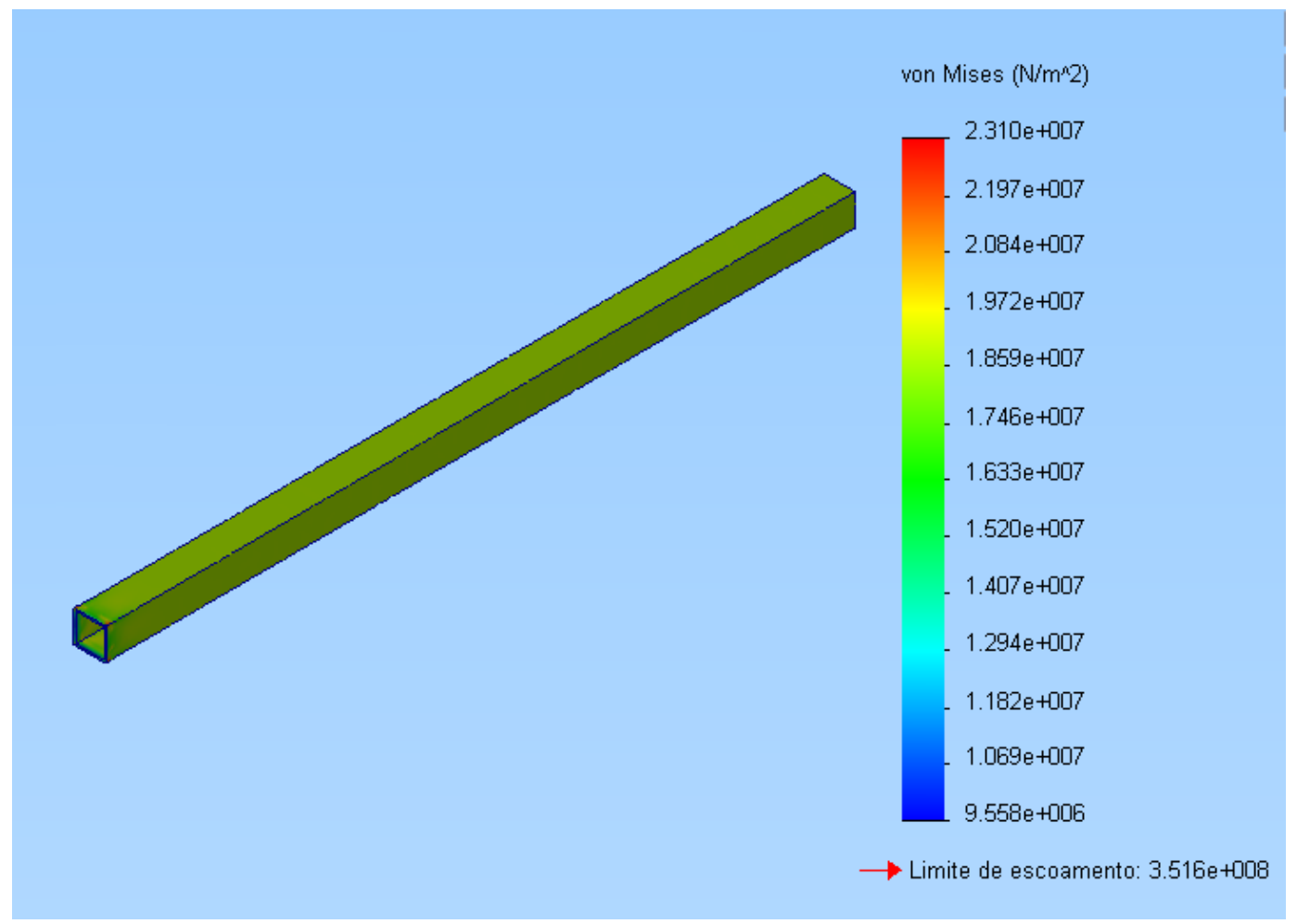

Figura 5A. Tensões na barra da treliça sob tração.

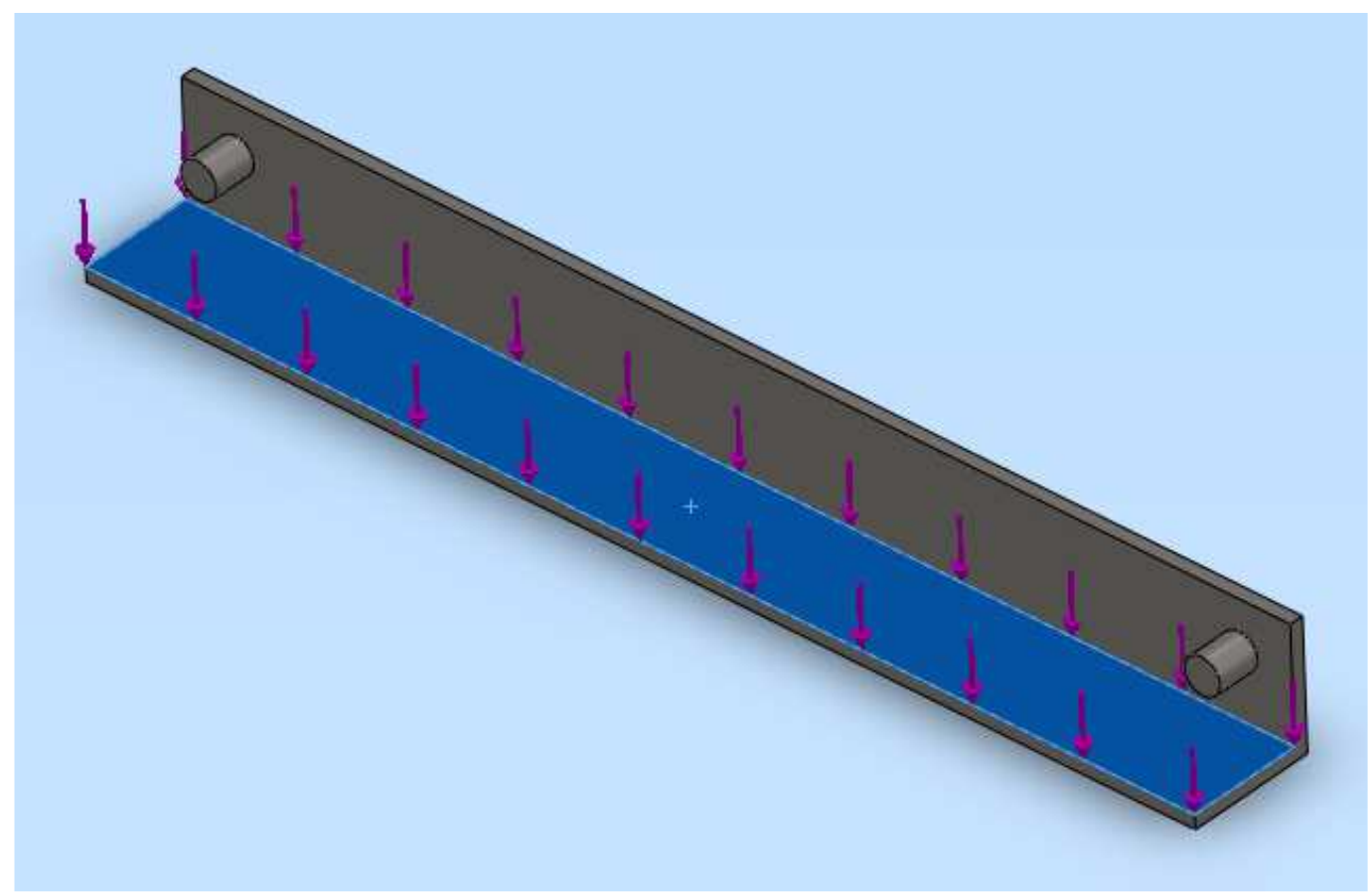

Figura 6A. Forma de aplicação do carregamento no carro do dispositivo vertical. 


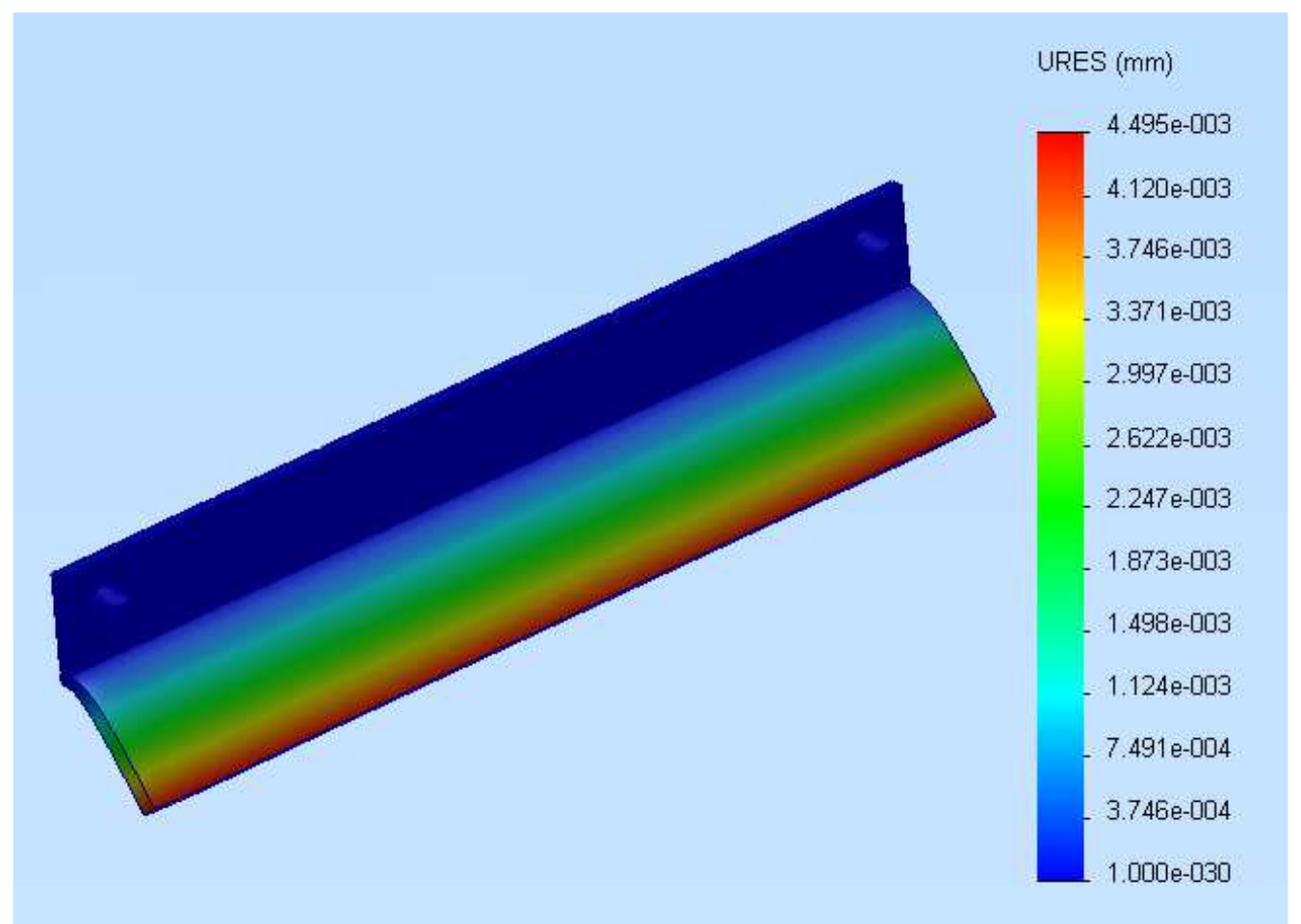

Figura 7A. Deformação do carro de ensaio vertical.

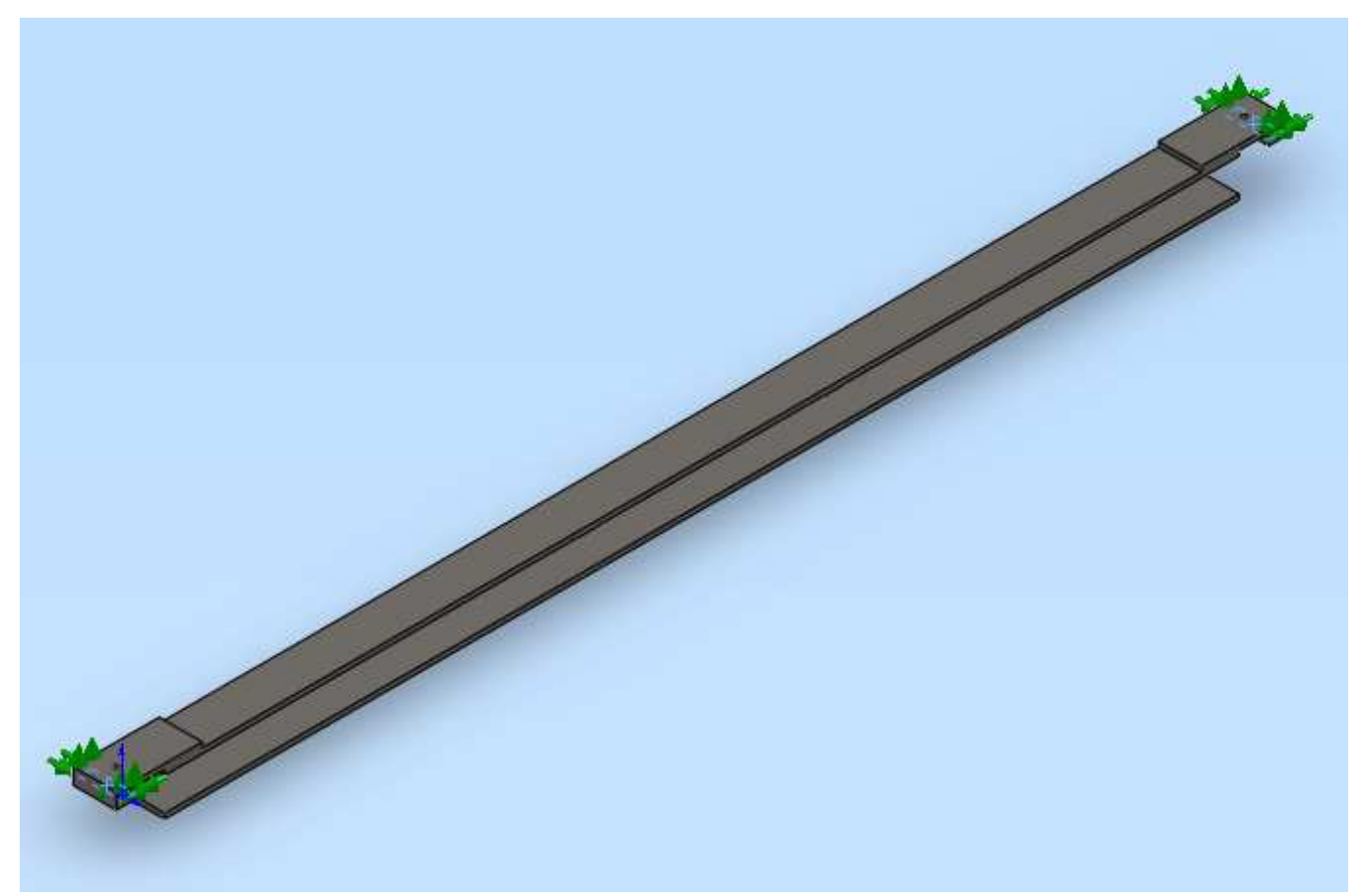

Figura 8A. Restrição na barra de apoio do carro horizontal. 


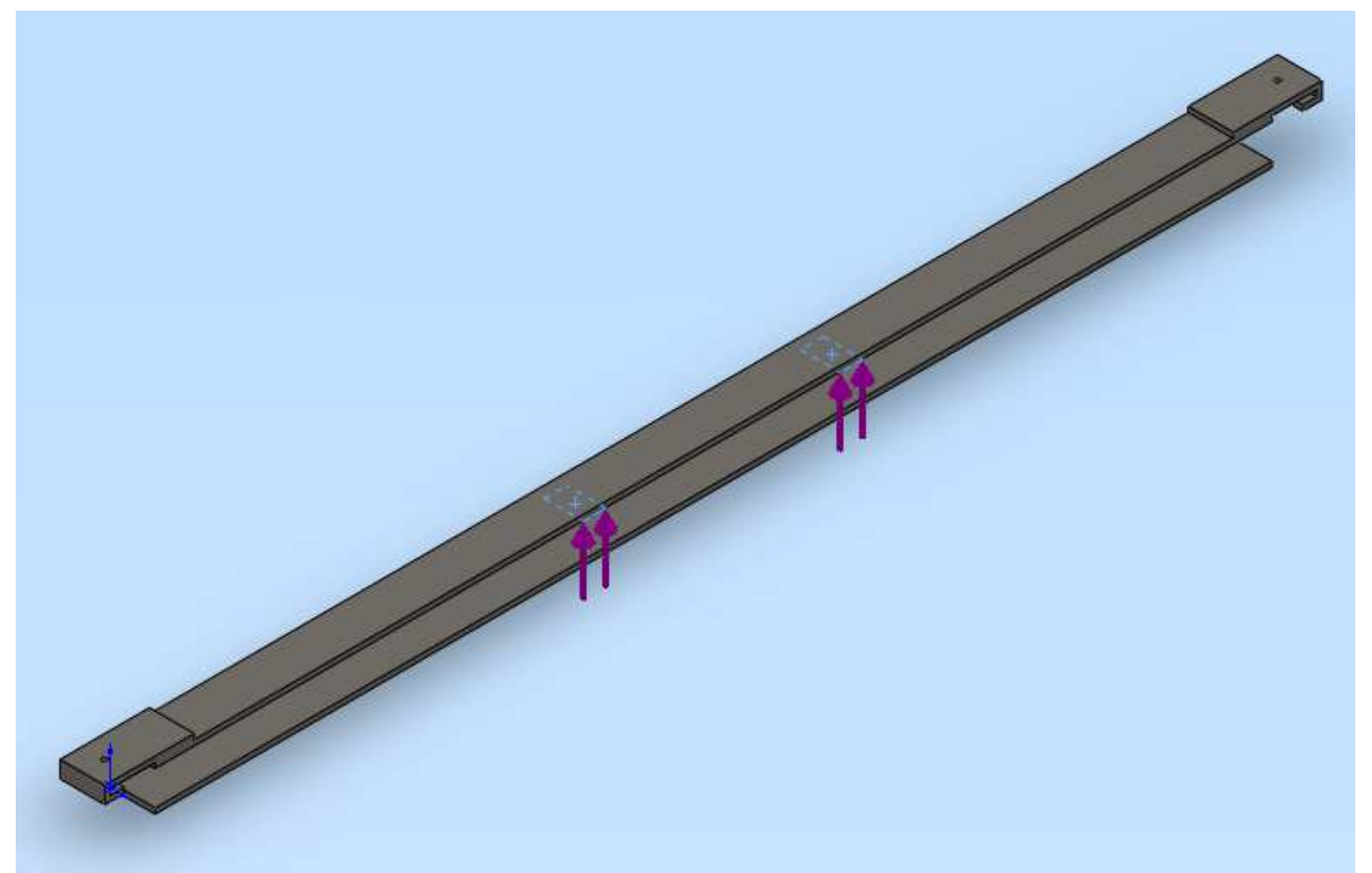

Figura 9A. Ponto de aplicação do carregamento na barra de apoio do carro horizontal 